\title{
Dual Roles of Glycosyl Torsion Angle Conformation and Stereochemical Configuration in Butadiene Oxide-Derived N1 $\beta$ - Hydroxyalkyl Deoxyinosine Adducts: A Structural Perspective†
}

\author{
W. Keither Merritt, Agnieszka Kowalczyk, Tandace A. Scholdberg, Stephen M. Dean, Thomas \\ M. Harris, Constance M. Harris, R. Stephen Lloyd, and Michael P. Stone \\ Department of Chemistry, Center in Molecular Toxicology, Vanderbilt-Ingram Cancer Center, \\ Vanderbilt University, Nashville, Tennessee 37235
}

\begin{abstract}
The solution structure of the N1-(1-hydroxy-3-buten-2(R)-yl)-2'-deoxyinosine adduct arising from the alkylation of adenine $\mathrm{N} 1$ by butadiene epoxide (BDO), followed by deamination to deoxyinosine, was determined, in the oligodeoxynucleotide $\mathrm{d}(\mathrm{CGGACXAGAAG)} \bullet \mathrm{d}(\mathrm{CTTCTCGTCCG})$. This oligodeoxynucleotide contained the BDO adduct at the second position of codon 61 of the human $N$-ras protooncogene, and was named the ras $61 \mathrm{R}$-N1-BDO- $(61,2)$ adduct. ${ }^{1} \mathrm{H}$ NMR revealed a weak $\mathrm{C}^{5} \mathrm{H}^{\prime}$ to $\mathrm{X}^{6} \mathrm{H} 8 \mathrm{NOE}$, followed by an intense $\mathrm{X}^{6} \mathrm{H} 8$ to $\mathrm{X}^{6} \mathrm{H} 1^{\prime}$ NOE. Simultaneously the $\mathrm{X}^{6} \mathrm{H} 8$ to $\mathrm{X}^{6} \mathrm{H} 3^{\prime} \mathrm{NOE}$ was weak. The resonances arising from the $\mathrm{T}^{16}$ and $\mathrm{T}^{17}$ imino protons were not observed. ${ }^{1} \mathrm{H}$ NOEs between the butadiene moiety and the DNA positioned the adduct in the major groove. Structural refinement based upon a total of 394 NOE-derived distance restraints and 151 torsion angle restraints yielded a structure in which the modified deoxyinosine was in the syn conformation about the glycosyl bond, with a glycosyl bond angle of $83^{\circ}$, and $\mathrm{T}^{17}$, the complementary nucleotide, was stacked into the helix, but not hydrogen bonded with the adducted inosine. The refined structure provides a plausible hypothesis as to why these N1 deoxyinosine adducts strongly code for the incorporation of dCTP during trans lesion DNA replication, irrespective of stereochemistry, both in Escherichia coli [Rodriguez, D.A., Kowalczyk, A., Ward, J.B.J., Harris, C.M., Harris, T.M., and Lloyd, R.S. (2001) Environ. Mol. Mutagen. 38, 292-296], and in mammalian cells [Kanuri, M., Nechev, L.N., Tamura, P.J., Harris, C.M., Harris, T.M., and Lloyd, R.S. (2002) Chem. Res. Toxicol. 15, 1572-1580]. Rotation of the N1 deoxyinosine adduct into the syn conformation may facilitate incorporation of dCTP via Hoogsteen-type templating with deoxyinosine, generating $\mathrm{A}$ to $\mathrm{G}$ mutations. However, conformational differences between the $R$ and $S$-N1-BDO- $(61,2)$ adducts, involving the positioning of the butenyl moiety in the major groove of DNA, suggest that adduct stereochemistry plays a secondary role in modulating the biological response to these adducts.
\end{abstract}

\footnotetext{
${ }^{\dagger}$ This work was supported by NIH grant ES-05509 (M.P.S.). Funding for the NMR spectrometers was supplied by Vanderbilt University; by NIH grant RR-05805, and the Vanderbilt Center in Molecular Toxicology, ES-00267. The Vanderbilt-Ingram Cancer Center is supported by NIH grant CA-68485.

*Author to whom correspondence should be addressed. Telephone 615-322-2589; FAX 615-322-7591; email michael.p.stone@vanderbilt.edu.

Current Address for Tandace Scholdberg: University of Kansas, Department of Medicinal Chemistry, Life Sciences Research Laboratories, 1501 Wakarusa, Lawrence, KS 66047

\$Current Address for Lubomir Nechev: Alnylam Pharmaceuticals, 790 Memorial Drive Suite 202, Cambridge, MA 02139

₹Center for Research on Environmental and Occupational Toxicology, Oregon Health and Science University, 3181 SW Sam Jackson Park Road, L606, Portland, OR 97239-3098
} 


\section{Introduction}

1,3-Butadiene (CAS RN 106-99-0) (BD) ${ }^{1}$ is used in the manufacture of styrene-butadiene rubber (SBR) $(1,2)$; several billion $\mathrm{lbs} / \mathrm{yr}$ are produced in the United States. It is a combustion product from automobile emissions (3) and cigarette smoke (4). BD is genotoxic and is a carcinogen in rodents, particularly in mice (5-7) and also in rats (8). Recently, BD was classified by the United States Environmental Protection Agency as "carcinogenic to humans by inhalation" (9). The International Agency for Cancer Research (IARC) lists BD as a "probable human carcinogen" (Group 2A) (10). Chronic human exposure in the SBR industry may induce genotoxic effects (11-13) and is correlated with increased risk for leukemia (1, 14-22).

$\mathrm{BD}$ is epoxidized primarily by cytochrome $\mathrm{P} 4502 \mathrm{E} 1$, but also by cytochrome $\mathrm{P} 4502 \mathrm{~A} 6$, to form 1,2-epoxy-3-butenes (BDO) (Scheme 1) $(23,24)$. BDO is a reactive electrophile that can potentially alkylate nucleophilic sites in DNA, including the imine nitrogen at N1 of deoxyadenosine. Alkylation could occur from either carbon atom of the oxirane; attack by the interior carbon atom, designated $\mathrm{C}_{\beta}$, yields two possible stereoisomers of the N1-(1-hydroxy-3buten-2-yl)-2'-deoxyadenosine adduct. These initially formed N1-dA adducts are prone to deamination (25), which yields two possible stereoisomeric N1-(1-hydroxy-3-buten-2-yl)-2'deoxyinosine adducts (Scheme 2).

Deamination of dA represents a pro-mutagenic event because during DNA replication, the resulting $\mathrm{dI}$ nucleotide is recognized as $\mathrm{dG}$ and preferentially pairs with incoming $\mathrm{dCTP}$ during DNA replication. However, in the N1-(1-hydroxy-3-buten-2-yl)-2'-deoxyinosine adducts, dI is alkylated at the N1 position, thus blocking base pairing with dCTP. Nevertheless, when ligated into the single-stranded vector M13mp7L2 that was used to transfect repair-deficient AB2480 (uvrA-, recA-) and SOS-proficient AB1157 Escherichia coli, the N1-(1-hydroxy-3buten-2(S)-yl)-2'-deoxyinosine adduct strongly coded for incorporation of dCTP (26). Studies of this adduct in COS-7 cells yielded similar results (27).

It was proposed that incorporation of dCTP opposite the N1-(1-hydroxy-3-buten-2(S)-yl)-2'deoxyinosine adduct might occur as a result of rotation of the N1-adducted dI into the syn conformation about the glycosyl bond, thus enabling formation of a protonated $\mathrm{dI} \bullet \mathrm{dC}$ Hoogsteen pair during trans-lesion synthesis (27) (Scheme 3). Structural studies of the N1-(1hydroxy-3-buten-2(S)-yl)-2'-deoxyinosine adduct site-specifically incorporated into the ras61 oligodeoxynucleotide 5'-d(CGGACX्XAGAAG)- 3'•5'-d(CTTCTTGTCCG)-3', containing the adduct at the second position of codon 61 , named the ras61 S-N1-BDO-(61,2) adduct, revealed the rotation of the glycosyl bond of the $S$-N1-BDO- $(61,2)$ adduct into the high syn conformation, thus placing the butadiene moiety into the major groove (28).

The present work characterizes the structural perturbation to the ras 61 oligodeoxynucleotide caused by the ras61 $R$-N1-BDO- $(61,2)$ adduct. Its structure is compared to the $S$-N1-BDO$(61,2)$ adduct $(28)$. Both the $R$ - and $S$-N1-BDO-(61,2) adducts induced $\mathrm{A} \rightarrow \mathrm{G}$ mutations. However, in the COS-7 system, the mutation frequencies differed with respect to adduct stereochemistry. The $R$-N1-BDO- $(61,2)$ adduct yielded a mutation frequency of $60 \%$, whereas the $S$-N1-BDO-(61,2) adduct yielded mutations at a frequency of $90 \%(27)$. Molecular dynamics calculations restrained by interproton distances obtained from nuclear Overhauser effects (29) and torsion angle restraints obtained from NMR data indicate that the $R$-N1-BDO-

\footnotetext{
${ }^{1}$ Abbreviations: BD, butadiene; BDE, 3,4-epoxy-1,2-butanediol; BDO, butadiene monoepoxide (1,2-epoxy-3-butene); $\mathrm{BDO}_{2}$, butadiene diepoxide (1,2:3,4-diepoxybutane); CPK, Corey-Pauling-Koltun space-filling models; DQF-COSY, double-quantum filtered correlation spectroscopy; HMBC, heteronuclear multiple bond correlation spectroscopy; $\mathrm{R}_{1} \mathrm{X}$, sixth root residual; rMD, restrained molecular dynamics; rmsd, root mean square deviation; SBR, styrene-butadiene rubber; TOCSY, total correlation spectroscopy; TPPI, timeproportional phase increment.
} 
$(61,2)$ adduct adduct assumes the syn conformation about the glycosyl bond in duplex DNA, whereas the $S$-N1-BDO- $(61,2)$ adduct glycosyl angle was in the "high-syn" conformation. In both instances the complementary dT remains intrahelical at the adduct site. The results suggest that that the predominance of $\mathrm{A} \rightarrow \mathrm{G}$ mutations observed for these adducts may be explained by the syn conformation observed at the glycosyl bond. On the other hand, stereospecific differences in adduct structure may correlate with differences in mutagenesis rate $(26,27)$.

\section{Materials and Methods}

\section{Sample Preparation}

The oligodeoxynucleotides $5^{\prime}$-d(CGGACAAGAAG)-3' and its complementary strand $5^{\prime}$-d (CTTCTTGTCCG)-3', were synthesized by the Midland Certified Reagent Co. (Midland, TX) and purified by anion-exchange chromatography. The concentrations of the single-stranded oligonucleotides were determined from their calculated extinction coefficients at $260 \mathrm{~nm}$ (30). The modified oligodeoxynucleotide (31) and its complement were annealed in $10 \mathrm{mM}$ $\mathrm{NaH}_{2} \mathrm{PO}_{4}, 10 \mathrm{mM} \mathrm{Na}_{2} \mathrm{HPO}_{4}, 0.1 \mathrm{M} \mathrm{NaCl}$, and $50 \mu \mathrm{M} \mathrm{Na} 2$ EDTA (pH 7.0). The modified duplex was eluted from DNA Grade Biogel hydroxylapatite (Bio-Rad Laboratories, Hercules, CA) with a gradient from 10 to $200 \mathrm{mM} \mathrm{NaH}_{2} \mathrm{PO}_{4}, \mathrm{pH}$ 7.0. It was desalted using Sephadex G-25. For NMR experiments, the modified duplex was prepared at a concentration of $2 \mathrm{mM}$. For observation of nonexchangeable protons, the sample was dissolved in $0.5 \mathrm{~mL}$ of $99.96 \%$ $\mathrm{D}_{2} \mathrm{O}$ containing $10 \mathrm{mM} \mathrm{NaH}_{2} \mathrm{PO}_{4}, 10 \mathrm{mM} \mathrm{Na}_{2} \mathrm{HPO}_{4}, 0.1 \mathrm{M} \mathrm{NaCl}$, and $50 \mu \mathrm{M} \mathrm{Na}_{2}$ EDTA at $\mathrm{pH}$ 7.0. For observation of exchangeable protons, the sample was dissolved in $0.5 \mathrm{~mL}$ of $9: 1$ $\mathrm{H}_{2} \mathrm{O}: \mathrm{D}_{2} \mathrm{O}$ in the same buffer.

\section{Capillary gel electrophoresis}

The purity of the modified duplex was analyzed using a PACE 5500 (Beckman Instruments, Inc., Fullerton, CA) instrument. Electrophoresis was conducted using an eCAP ssDNA 100-R kit applying 12,000 V for $30 \mathrm{~min}$. The electropherogram was monitored at $254 \mathrm{~nm}$.

\section{Mass Spectrometry}

MALDI-TOF mass spectra were measured on a Voyager-DE (PerSeptive Biosystems, Inc., Foster City, CA) instrument in negative reflector mode. The matrix contained $0.5 \mathrm{M} 3$ hydroxypicolinic acid and $0.1 \mathrm{M}$ ammonium citrate.

\section{Nuclear Magnetic Resonance}

${ }^{1} \mathrm{H}$ NMR spectra were recorded at $600.13 \mathrm{MHz}$ and 800.23 MHz. The non-exchangeable protons were monitored at $25^{\circ} \mathrm{C}$; the exchangeable protons were monitored at $17^{\circ} \mathrm{C}$. Chemical shifts were referenced to the water resonance. NMR data were processed using FELIX2000 (Accelyris, Inc., San Diego, CA).

NOESY spectra of the non-exchangeable protons were recorded using TPPI phase cycling with mixing times of 150,200 , and $250 \mathrm{~ms}$. These were acquired sequentially without removing the sample from the magnet. Spectra for the exchangeable protons were recorded using a $150 \mathrm{~ms}$ mixing time. These experiments were recorded with 1024 real data points in the d1 dimension and 2048 real data points in the $\mathrm{d} 2$ dimension. A relaxation delay of $2.0 \mathrm{~s}$ was used. Water suppression was performed using the WATERGATE sequence (32). TOCSY experiments were performed with mixing times of 90 and $150 \mathrm{~ms}$, utilizing the homonuclear Hartman-Hahn transfer with the MLEV17 sequence for mixing. DQF-COSY spectra were zero-filled to give a matrix of $1024 \times 2048$ real points. A skewed sine-bell square apodization function with a $90^{\circ}$ phase shift and a skew factor of 1.0 was used in both dimensions. 


\section{Experimental Restraints}

(a) Distance Restraints: Footprints were drawn around cross peaks obtained at a mixing time of $200 \mathrm{~ms}$ using FELIX2000. Identical footprints were transferred and fit to the crosspeaks obtained at the other two mixing times. The intensities of these cross peaks were determined by volume integration. These were combined as necessary with intensities generated from complete relaxation matrix analysis of a starting DNA structure to generate a hybrid intensity matrix $(33,34)$. MARDIGRAS (35-37) was used to iteratively refine the hybrid intensity matrix and to optimize the agreement between the calculated and experimental NOE intensities. Calculations were initated using isotropic correlation times of 2, 3, and $4 \mathrm{~ns}$, and with both IniA and IniB starting structures and the three mixing times, yielding eighteen sets of distances. Analysis of this data yielded the experimental distance restraints used in subsequent restrained molecular dynamics calculations, and the corresponding standard deviations for the distance restraints. The distance restraints were divided into five classes, reflecting the confidence level in the experimental data.

(b) Torsion Angle Restraints: Deoxyribose pseudorotation (57) was determined graphically using the sums of ${ }^{3} \mathrm{~J}{ }^{1} \mathrm{H}$ coupling constants (58), measured from DQF-COSY spectra. Discrete $\mathrm{J}_{1^{\prime} 2^{\prime \prime}}$ and $\mathrm{J}_{1^{\prime} 2^{\prime}}$ couplings were measured from active and passive couplings, respectively, of the $\mathrm{H} 2$ " (d2) to H1' (d1) spectral region. The data were fit to curves relating the coupling constants to the deoxyribose sugar pseudo rotation angle (P), sugar pucker amplitude $(\varphi)$, and the percentage $\mathrm{S}$-type conformation. The sugar pseudo rotation angle and amplitude ranges were converted to the five dihedral angles $v_{0}$ to $v_{4}$. Coupling constants measured from ${ }^{1} \mathrm{H}_{-}{ }^{31} \mathrm{P} \mathrm{HMBC}$ spectra were applied $(38,39)$ to the Karplus relationship $(40)$ to determine the backbone dihedral angle $\varepsilon\left(\mathbf{C 4}^{\prime}-\mathbf{C 3}^{\prime}-\mathbf{O 3}^{\prime}-\mathrm{P}\right)$, related to the $\mathrm{H}^{\prime}-\mathbf{C 3}^{\prime}-\mathbf{O 3}^{\prime}$-P angle by a $120^{\circ}$ shift. The $\zeta$ $\left(\mathrm{C}^{\prime}\right.$-O3'-P-O5') backbone angles were calculated from the correlation between $\varepsilon$ and $\zeta$ in BDNA (60).

\section{Restrained Molecular Dynamics Calculations}

Classical A-DNA and B-DNA were used as reference structures to create starting structures for the refinement (41). The butadiene adduct was constructed at $X^{6}$ using the BUILDER module of INSIGHT II (Accelrys, Inc., San Diego, CA). A-form and B-form structures of the appropriate sequence were energy-minimized by the conjugate gradients method for 200 iterations using the AMBER 7.0 force field (42) without experimental restraints to give starting IniA and IniB used for the subsequent relaxation matrix analysis and molecular dynamics calculations. The restraint energy function was comprised of terms describing distances and dihedral restraints, both of which were in the form of a standard square-well potential (43). Bond lengths involving hydrogens were fixed with the SHAKE algorithm (44). The generalized Born approach was used to model solvation $(45,46)$. The calculations utilized a salt concentration of $0.2 \mathrm{mM}$. A series of randomly seeded rMD calculations were performed over a time course of $40 \mathrm{ps}$. These used the SANDER module of AMBER 7.0, and the Cornell et al. force field (47), including the Parm94.dat parameter set. The simulated annealing protocol utilized a starting temperature of $25 \mathrm{~K}$. In the first ps the temperature was increased to $600 \mathrm{~K}$. This was maintained for the next $4 \mathrm{ps}$, followed by cooling to $298 \mathrm{~K}$ over $15 \mathrm{ps}$. During the final $20 \mathrm{ps}$ the temperature was reduced to $0 \mathrm{~K}$. Temperature was controlled by coupling the molecules to a temperature bath. During the first 1 ps of heating a coupling of $0.4 \mathrm{ps}$ was used. During the next $4 \mathrm{ps}$ of constant temperature dynamics a coupling of $1.0 \mathrm{ps}$ was used. In the first $15 \mathrm{ps}$ of cooling, a value of $1.0 \mathrm{ps}$ was used, followed by a value of $0.5 \mathrm{ps}$ for the second $15 \mathrm{ps}$. During the final $5 \mathrm{ps}$ of cooling, the coupling was ramped down to $0.01 \mathrm{ps}$. In the first $1 \mathrm{ps}$ of heating, the experimental force constants were amplified by factors that ranged from 0.5 to 1.00 . During the $4 \mathrm{ps}$ of constant temperature dynamics and the first $15 \mathrm{ps}$ of cooling, the amplification factor was increased to 1.75 . In the final $20 \mathrm{ps}$ of cooling, the amplification factor was reduced to a value of 1.00 . Structure coordinates were archived every 0.1 ps over 
the final $10 \mathrm{ps}$ of the rMD simulation. Structure coordinates extracted from the final $4 \mathrm{ps}$ of each rMD calculation were averaged and energy-minimized for 200 iterations using the conjugate gradients algorithm. An average structure was obtained from eight randomly seeded rMD calculations.

Back-calculation of ${ }^{1} \mathrm{H}$ NOE data was performed using CORMA (v. 4.0) (48). Helicodial parameters were examined using 3DNA (49).

\section{Results}

\section{Sample Properties}

The duplex $R$-N1-BDO- $(61,2)$ oligodeoxynucleotide yielded two sharp bands in a 1:1 ratio, corresponding to the modified and complementary strands, when assessed using capillary gel electrophoresis. MALDI-TOF mass spectrometry showed two signals that corresponded to the anticipated mass units of 3468 (adducted strand) and 3272 (complementary strand). The melting temperature of the $R$-N1-BDO- $(61,2)$ duplex as determined by UV spectroscopy was $33^{\circ} \mathrm{C}(50)$, less than the observed $57^{\circ} \mathrm{C}$ melting temperature of the unmodified ras61 duplex. The $R$-N1-BDO- $(61,2)$ sample yielded excellent NMR data in the temperature range of $15^{\circ}$ $\mathrm{C}--25^{\circ} \mathrm{C}$.

\section{DNA ${ }^{1} \mathrm{H}$ Resonance Assignments}

(a) Nonexchangeable Protons-The sequential ${ }^{1} \mathrm{H}$ NOEs between the aromatic and anomeric protons of the $R$-N1-BDO-(61,2) oligodeoxynucleotide duplex are displayed in Figure 1. The NMR spectrum was well-resolved and yielded resonances with narrow linewidths, indicative of a stable and ordered conformation. These resonances were assigned using standard methods $(51,52)$. The remarkable features of this region of the ${ }^{1} \mathrm{H} N O E$ spectrum were the weak $\mathrm{C}^{5} \mathrm{H} 1^{\prime} \rightarrow \mathrm{A}^{6} \mathrm{H} 8$ and $\mathrm{X}^{6} \mathrm{H} 1^{\prime} \rightarrow \mathrm{A}^{7} \mathrm{H} 8$ crosspeaks. With respect to the complementary strand, all sequential NOEs were observed, although the $\mathrm{T}^{17} \mathrm{H} 1^{\prime} \rightarrow \mathrm{G}^{18} \mathrm{H} 8$ NOE was weak. The deoxyribose sugar proton resonances were assigned from DQF-COSY spectra. A complete ${ }^{1} \mathrm{H}$ assignment was achieved, with the exception of several of the $\mathrm{H} 5^{\prime}$ and $\mathrm{H} 5$ " protons. The ${ }^{1} \mathrm{H}$ NMR assignments are provided in Table S1 of the Supporting Information.

(b) Exchangeable Protons-An expanded region showing the far downfield region of the ${ }^{1} \mathrm{H}$ NOE spectrum, exhibiting cross-peaks between the hydrogen-bonded imino protons is shown in Figure 2. As compared to the unmodified ras61 duplex (31), the primary changes in the spectrum were the lack of signals for base pairs $\mathrm{X}^{6} \cdot \mathrm{T}^{17}$ and $\mathrm{A}^{7} \cdot \mathrm{T}^{16}$. In the amino region of the ${ }^{1} \mathrm{H}$ NMR spectrum, the NOE between $\mathrm{A}^{7} \mathrm{H} 2 \rightarrow \mathrm{T}^{16} \mathrm{~N} 3 \mathrm{H}$ was also not observed, eliminating the possibility that the $\mathrm{T}^{14} \mathrm{~N} 3 \mathrm{H}$ and $\mathrm{T}^{16} \mathrm{~N} 3 \mathrm{H}$ resonances were overlapped, as had been observed for the $S$-N1-BDO-(61,2) duplex (28). Consequently, the sequential NOE connectivity in the imino region of the ${ }^{1} \mathrm{H}$ spectrum was interrupted at base pair $\mathrm{C}^{5} \cdot \mathrm{G}^{18}$ and resumed at base pair $\mathrm{G}^{8} \cdot \mathrm{C}^{15}$. The NOE between $\mathrm{T}^{13} \mathrm{~N} 3 \mathrm{H}$ and $\mathrm{T}^{14} \mathrm{~N} 3 \mathrm{H}$ was weak. It was not observed at the contour level plotted in Figure 2. It was also weak in the spectrum of the unmodified ras61 oligodeoxynucleotide (31), and presumably reflects a sequence-specific rapid exchange of this proton with solvent. The imino protons of the terminal $\mathrm{C}^{1} \cdot \mathrm{G}^{22}$ pair and $\mathrm{G}^{11} \cdot \mathrm{C}^{12}$ pairs were not detected, presumably due to fraying of the ends of the helices.

(c) Butadiene Protons-The butadiene proton assignments were achieved using a combination of NOESY and COSY experiments ${ }^{2}$ (Figure 3). The protons $\mathrm{H}_{\gamma}$ and $\mathrm{H}_{\delta^{\prime}}$

\footnotetext{
${ }^{2}$ The definitions of the prochiral protons at $\mathrm{C}_{\alpha}$ of the BD moiety are based upon the Cahn, Ingold, and Prelog nomenclature. The proton $\mathrm{H}_{\alpha^{\prime}}$ is defined as the pro- $R$ proton at $\mathrm{C}_{\alpha^{\prime}} \cdot \mathrm{H}_{\alpha^{\prime \prime}}$ is defined as the pro-S proton at $\mathrm{C}_{\alpha}$.
} 
overlapped at $5.40 \mathrm{ppm}$, and the proton $\mathrm{H}_{\delta^{\prime \prime}}$ resonated at $5.43 \mathrm{ppm}$. The proton $\mathrm{H}_{\beta}$ was assigned at $4.76 \mathrm{ppm}$. It exhibited NOEs to two protons that resonated at 3.22 and $3.40 \mathrm{ppm}$, which were assigned as the $\mathrm{H}_{\alpha^{\prime}, \alpha^{\prime \prime}}$ protons. The $\mathrm{H}_{\alpha^{\prime}, \alpha^{\prime \prime}}$ assignments were based upon potential energy minimization calculations, which predicted that the lowest energy conformation of the $R$-N1$\mathrm{BD}$ moiety placed the hydroxyl at $\mathrm{C}_{\alpha}$ such that the hydroxyl proton was within hydrogen bonding distance of the inosine keto oxygen, $\mathrm{X}^{6} \mathrm{O}^{6}$. In this conformation $\mathrm{H}_{\alpha^{\prime}}$ was expected to exhibit a stronger NOE to $\mathrm{H}_{\delta^{\prime}}$ and a weaker NOE to $\mathrm{H}_{\delta^{\prime \prime}}$, whereas $\mathrm{H}_{\alpha^{\prime \prime}}$ was expected to exhibit only weak NOEs to $\mathrm{H}_{\delta^{\prime}}$ and $\mathrm{H}_{\delta^{\prime \prime}}$. Accordingly, the resonance at $3.42 \mathrm{ppm}$ was assigned as $\mathrm{H}_{\alpha^{\prime}}$ and the resonance at $3.45 \mathrm{ppm}$ was assigned as $\mathrm{H}_{\alpha^{\prime \prime}}$. The BD protons exhibited spectral linewidths comparable to those of the oligodeoxynucleotide protons.

(d) Butadiene-DNA NOEs-These were observed between the BD moiety and major groove protons associated with the modified base pair $\mathrm{X}^{6} \cdot \mathrm{T}^{17}$ and its $3^{\prime}$-neighbor base pair, $\mathrm{A}^{7} \cdot \mathrm{T}^{16}$ (Figure 3 ). The proton $\mathrm{H}_{\gamma}$ exhibited a strong NOE to $\mathrm{X}^{6} \mathrm{H} 2$, which may also be observed in Figure 1 . The $\mathrm{H}_{\gamma}$ resonance overlapped with that arising from $\mathrm{H}_{\delta^{\prime}}$, but the primary NOE was anticipated to arise from the $\mathrm{X}^{6} \mathrm{H} 2 \rightarrow \mathrm{H}_{\gamma}$ dipolar interaction. Crosspeaks in the NOESY spectrum were also observed between $\mathrm{X}^{6} \mathrm{H} 2$, and $\mathrm{BD} \mathrm{H}_{\beta}$ and $\mathrm{H}_{\alpha^{\prime}, \alpha^{\prime \prime}}$ protons. The latter NOEs probably resulted from spin diffusion at the $200 \mathrm{~ms}$ mixing time shown in Figure 3.

\section{Torsion Angle Measurements}

The glycosyl torsion angle conformations were evaluated by inspection of ${ }^{1} \mathrm{H}$ NOESY data. Figure 4 details the relative intensities of intranucleotide NOEs between purine $\mathrm{H} 8$ and pyrimidine $\mathrm{H} 6$ protons, and anomeric $\mathrm{H} 1$ ' protons for the adducted strand of the $R$-N1-BDO$(61,2)$ adduct. The strong NOE between $\mathrm{X}^{6} \mathrm{H} 8$ and $\mathrm{X}^{6} \mathrm{H} 1^{\prime}$ was evident, indicating that the $\mathrm{X}^{6}$ inosine ring was in the syn conformation. Weaker NOEs between the other purine $\mathrm{H} 8$ or pyrimidine $\mathrm{H} 6$ protons and the anomeric $\mathrm{H}^{\prime}$ protons of the attached deoxyribose sugars were consistent with glycosyl torsion angles in the anti conformational range. Analysis of DQFCOSY data suggested that all deoxyribose pseudorotation angles remained in the $\mathrm{C} 2$ '-endo range anticipated for B-family DNA. There were no unusually shifted ${ }^{31} \mathrm{P}$ resonances.

\section{Chemical Shift Perturbations}

Figure 5 shows chemical shift differences between the $R$-N1-BDO- $(61,2)$ adduct and the unmodified ras61 duplex oligodeoxynucleotide (31). The changes were observed at the four base pairs $\mathrm{C}^{5} \cdot \mathrm{G}^{18}, \mathrm{X}^{6} \cdot \mathrm{T}^{17}, \mathrm{~A}^{7} \cdot \mathrm{T}^{16}$, and $\mathrm{G}^{8} \cdot \mathrm{C}^{15}$. Of the DNA base aromatic protons, $\mathrm{A}^{7} \mathrm{H} 8$ shifted 0.2 ppm upfield, $\mathrm{C}^{15} \mathrm{H} 5$ shifted 0.4 ppm upfield, and $\mathrm{G}^{18} \mathrm{H} 8$ shifted 0.2 ppm upfield. A downfield shift of $0.3 \mathrm{ppm}$ was observed for $\mathrm{X}^{6} \mathrm{H} 8$. $\mathrm{T}^{16} \mathrm{H} 6$ shifted downfield $0.15 \mathrm{ppm}$, and $\mathrm{T}^{17} \mathrm{H} 6$ shifted downfield $0.2 \mathrm{ppm}$. Of the deoxyribose $\mathrm{H} 1^{\prime}$ protons $\mathrm{C}^{5} \mathrm{H} 1^{\prime}$ shifted 0.45 ppm upfield, $\mathrm{G}^{8} \mathrm{H} 8$ shifted $0.15 \mathrm{ppm}$ upfield, and $\mathrm{T}^{16} \mathrm{H} 1^{\prime}$ shifted $0.2 \mathrm{ppm}$ upfield. In contrast, $\mathrm{X}^{6} \mathrm{H} 1^{\prime}$ shifted 0.2 ppm downfield, $\mathrm{A}^{7} \mathrm{H} 1^{\prime}$ shifted 0.4 ppm downfield, $\mathrm{G}^{8} \mathrm{H} 1^{\prime}$ shifted $0.15 \mathrm{ppm}$ downfield, $\mathrm{T}^{17} \mathrm{H} 1^{\prime}$ shifted $0.15 \mathrm{ppm}$ downfield, and $\mathrm{G}^{18} \mathrm{H} 1^{\prime}$ shifted $0.2 \mathrm{ppm}$ downfield. At $\mathrm{X}^{6}$ there were noticeable changes in chemical shift for the $\mathrm{H} 2^{\prime}$ and $\mathrm{H} 2^{\prime \prime}$ protons.

\section{Structural Refinement}

The experimental distance restraints generated by MARDIGRAS were evenly distributed over the length of the $R$-N1-BDO- $(61,2)$ oligodeoxynucleotide. The presence of the $R$-N1-BDO$(61,2)$ adduct at nucleotide $\mathrm{X}^{6}$ resulted in a greater number of NOE restraints at nucleotides $\mathrm{C}^{5}$ and $\mathrm{X}^{6}$; these served to orient the BD moiety in the duplex DNA. In addition to the distance restraints, eighty deoxyribose pseudorotation restraints were included. Fifty empirical WatsonCrick hydrogen bonding restraints (53) were included in the calculations. Hydrogen-bonding restraints were not used for $\mathrm{X}^{6} \cdot \mathrm{T}^{17}$ and its $3^{\prime}$-neighbor $\mathrm{A}^{7} \cdot \mathrm{T}^{16}$, as ${ }^{1} \mathrm{H}$ NOESY data did not indicate Watson-Crick base-pairing at these base pairs. There were 71 empirical 
phosphodiester backbone torsion angle restraints used in the rMD calculations. These restrained the torsion angles $\varepsilon$ and $\zeta$ at angles of $165^{\circ} \pm 35^{\circ}$ and $245^{\circ} \pm 35^{\circ}$ respectively (54).

A stereoview of structures originating from a series of randomly seeded rMD calculations is shown in Figure 6. These rMD calculations utilized both A-form and B-form DNA starting structures, which exhibited a difference rmsd of $5.92 \AA$. Utilizing either starting structure, the rMD calculations converged to similar structures. The maximum pairwise rmsd between structures emergent from the rMD calculations was $1.35 \AA$. The average refined structure showed a rmsd of $2.17 \AA$ compared to the B-DNA starting structure, whereas it showed a 7.34 $\AA$ rmsd compared to the A-DNA starting structure. Thus, the structures emergent from the rMD calculations were different than either A-form or B-form DNA, consistent with the observation that the modified nucleotide $\mathrm{X}^{6}$ was in the syn conformation about the glycosyl bond. The structural refinement statistics are presented in Table 1.

The accuracies of the refined structures were evaluated using complete relaxation matrix calculations, and comparison of the resulting theoretical crosspeak intensities with the ${ }^{1} \mathrm{H} \mathrm{NOE}$ data (Figure 7). These yielded sixth root residual $\left(\mathrm{R}_{1}{ }^{\mathrm{x}}\right)$ values of $9.2 \times 10^{-2}$ for intranucleotide and $9.3 \times 10^{-2}$ for internucleotide NOEs. The residual values were reasonably consistent over the length of the oligodeoxynucleotide.

\section{Structure of the $R$-N1-BDO- $(61,2)$ Adduct}

The N1 BD adduct induced a significant structural perturbation to the modified oligodeoxynucleotide (Figure 8). The predominant feature was the syn conformation at the N1adducted inosine $\mathrm{X}^{6}$. This placed the BD moiety into the major groove of the DNA duplex. The vinyl group was positioned in the $5^{\prime}$ direction of the duplex, while the hydroxymethyl group was positioned in the $3^{\prime}$ direction. The nucleotide complementary to $\mathrm{X}^{6}, \mathrm{~T}^{17}$, tilted into the minor groove and did not hydrogen bond with $\mathrm{X}^{6}$. Base pair $\mathrm{A}^{7} \cdot \mathrm{T}^{16}$ was also disrupted. The purine ring of $\mathrm{A}^{7}$ tilted toward the major groove and was out-of-plane with its complement $\mathrm{T}^{16}$, thus precluding Watson-Crick hydrogen bonding at this base pair. Thus, Watson-Crick hydrogen bonding was disrupted both at the modified base pair $\mathrm{X}^{6} \cdot \mathrm{T}^{17}$, and at its $3^{\prime}$-neighbor, $\mathrm{A}^{7} \cdot \mathrm{T}^{16}$.

Figure 9 shows the base stacking orientations, as predicted by rMD calculations, at base pairs $\mathrm{C}^{5} \cdot \mathrm{G}^{18}, \mathrm{X}^{6} \cdot \mathrm{T}^{17}$, and $\mathrm{A}^{7} \cdot \mathrm{T}^{16}$ of the $R$-N1-BDO- $(61,2)$ duplex. The rotation of $\mathrm{X}^{6}$ into the syn conformation about the glycosyl bond, placing the N1 BD adduct into the major groove, can be observed. $\mathrm{T}^{17}$, the nucleotide complementary to $\mathrm{X}^{6}$, remained stacked within the double helix. In the modified strand, the imidazole ring of $\mathrm{X}^{6}$ stacked above the pyrimidine ring of $\mathrm{A}^{7}$. The stacking patterns in the complementary strand of the duplex were relatively unperturbed. Figure 9 also compares stacking interactions of the $R$-N1-BDO-(61,2) duplex with the $S$-N1-BDO- $(61,2)$ duplex $(28)$ and the unmodified ras61 duplex $(31)$. In both the Rand $S$-N1-BDO-(61,2) duplexes, the modified nucleotide $\mathrm{X}^{6}$ rotated about the glycosyl bond, in both instances placing the BD moiety into the major groove. The major difference in stacking between the two diastereomeric N1 adducts was an increased base pair opening at $\mathrm{X}^{6} \cdot \mathrm{T}^{17}$ for the $S$-N1-BDO- $(61,2)$ adduct, which was in the high syn conformation $(28)$. The $S$-N1-BDO$(61,2)$ adduct exhibited essentially no intrastrand stacking interactions between nucleotides $\mathrm{C}^{5}, \mathrm{X}^{6}$, and $\mathrm{A}^{7}$.

\section{Discussion}

The $R$-N1-BDO- $(61,2)$ adduct was significantly mutagenic. Like the $S$-N1-BDO- $(61,2)$ adduct of opposite stereochemistry, it strongly coded for incorporation of dCTP, both in Escherichia coli (26) and in COS-7 cells (27). Studies of the $S$-N1-BDO- $(61,2)$ adduct revealed the rotation of the glycosyl bond into the high syn conformation. This placed the butadiene moiety into the 
major groove (28). The earlier studies suggested that butadiene-induced $\mathrm{A} \rightarrow \mathrm{G}$ mutations might accrue from three coupled events: (1) alkylation of the N1 imine nitrogen of adenine by butadiene mono- or di-epoxides, (2) deamination of the initially formed N1-dA adducts, and (3) the rotation of the resulting N1-dI adducts about the glycosyl bond into the syn conformation, facilitating Hoogsteen hydrogen bonding with incoming dCTP (27) (Scheme 3). Significantly, this model predicted that deamination was essential to generating $A \rightarrow G$ mutations, since the N1-dA adduct itself would not be expected to form a Hoogsteen pairing interaction with incoming dCTP. It also predicted that the conformation of the glycosyl bond was the key determinant of mutagenic outcome, as opposed to adduct stereochemistry, thus providing a rationale for the observation that both the $R$ - and $S$-N1-BDO- $(61,2)$ adducts coded for incorporation of dCTP $(26,27)$. Consequently, it was of interest to examine the structure of the $R$-N1-BDO- $(61,2)$ adduct.

\section{Structure of the R-N1-BDO-(61,2) Adduct}

The present results indicate, that like the $S$-N1-BDO- $(61,2)$ adduct, the $R$-N1-BDO- $(61,2)$ adduct also undergoes rotation about the glycosyl bond, into the syn conformation. The crosspeak intensity between $\mathrm{X}^{6} \mathrm{H} 8$ and $\mathrm{X}^{6} \mathrm{H} 1^{\prime}$ was large, indicative of the close proximity of the anomeric and imidazole protons in the syn conformation. The pattern of NOEs between the $R$-N1-BDO- $(61,2)$ adduct and the DNA firmly established the major groove orientation of the adduct. NOEs were observed between the BD moiety and major groove protons at $\mathrm{C}^{5}, \mathrm{X}^{6}$, $\mathrm{A}^{7}, \mathrm{~T}^{16}$, and $\mathrm{T}^{17}$. The failure to observe NMR resonances from the imino protons at nucleotides $\mathrm{T}^{16}$ and $\mathrm{T}^{17}$, indicative of rapid exchange with solvent (Figure 2) corroborated the predicted loss of Watson-Crick hydrogen bonding at base pairs $\mathrm{X}^{6} \cdot \mathrm{T}^{17}$ and $\mathrm{A}^{7} \cdot \mathrm{T}^{16}$. The reduction in the melting temperature for the $R$-N1-BDO- $(61,2)$ adduct to $33^{\circ} \mathrm{C}(50)$, less than the observed $57^{\circ}$ $\mathrm{C}$ melting temperature of the unmodified ras 61 duplex, was consistent with this conclusion. The altered base stacking at nucleotides $\mathrm{C}^{5}, \mathrm{X}^{6}$, and $\mathrm{A}^{7}$ (Figure 10) was observed spectroscopically in the form of chemical shift perturbations clustered at these three base pairs (Figure 6).

\section{Structure-Activity Relationships}

(a) Conformation of the Glycosyl Torsion Angle-The finding that for both the $R$-N1BDO- $(61,2)$ and $S$-N1-BDO-(61,2) adducts $(28)$, the N1-adducted dI nucleotide rotated about the glycosyl bond, into the syn (this work) or high syn (S-N1-BDO-(61,2) adduct) conformations supports the notion that the conformation of the glycosyl bond is the key determinant of mutagenic outcome for these N1-dI adducts. Placing the glycosyl bond in the syn or high syn conformation would allow the adducted base to pair with a protonated dCTP during trans-lesion replication (Scheme 3). Simultaneously, rotation about the glycosyl bond places the $\mathrm{BD}$ stereocenter at $\mathrm{C}_{\beta}$ into the major groove, such that it would not be expected to interfere with Hoogsteen-type templating involving $\mathrm{O}^{6}$ and $\mathrm{N} 7$ of the inosine nucleobase. This would presumably yield the observed $\mathrm{A} \rightarrow \mathrm{G}$ mutations, irrespective of adduct stereochemistry, consistent with observation (27). Structural studies of the $R$-N1-BDO- $(61,2)$ and $S$-N1-BDO$(61,2)$ adducts opposite dCTP to further examine this hypothesis should now be of considerable interest.

(b) Stereospecific processing-Although the present results suggest that stereochemistry of the $R$-N1-BDO- $(61,2)$ and $S$-N1-BDO- $(61,2)$ adducts is not the primary determinant of mutagenic outcome, the two stereoisomeric adducts showed differential levels of mutations. Comparable studies using the $R$-N1-BDO- $(61,2)$ and $S$-N1- BDO- $(61,2)$ adducts gave rise to $\mathrm{A} \rightarrow \mathrm{G}$ transitions with overall mutagenic frequencies of 60 and $90 \%$, respectively (27). When ligated into 51-mer templates, and examined as to trans-lesion replication in vitro, the $R$-N1BDO- $(61,2)$ or the $S$-N1-BDO- $(61,2)$ adducts posed significant blocks to replication by repairdeficient E. coli polymerase III (26). Replication efficiency of the adduct-containing DNAs 
were found to be reduced to $10 \%$ of the wild type for the $S$-N1-BDO- $(61,2)$ adduct and $25 \%$ for the $R$-N1-BDO- $(61,2)$ adduct. Collectively, these observations suggest that while conformation of the glycosyl bond is the primary determinant of $\mathrm{A} \rightarrow \mathrm{G}$ mutations, adduct stereochemistry provides a secondary contribution with regard to differences in the biological processing of these N1-dI adducts.

One significant structural difference between the $R$ - and $S$-N1-BDO- $(61,2)$ adducts was the orientation of the $\mathrm{BD}$ moiety. In the $R$-N1-BDO- $(61,2)$ adduct the vinyl group was oriented in the $5^{\prime}$ direction of the adducted strand. In contrast, it was oriented in the $3^{\prime}$ direction in the $S$ N1-BDO-(61,2) oligodeoxynucleotide (28) (Figure 8). This had several consequences, which may be significant with regard to stereospecific differences in the processing of the N1 lesions. For the $R$-N1-BDO- $(61,2)$ duplex the vinyl group bridged the floor of the major groove between the adducted nucleotide $\mathrm{X}^{6}$ and its complement, $\mathrm{T}^{17}$. In contrast, for the $S$-N1-BDO-(61,2) duplex, the vinyl group was oriented away from the floor of the major groove and into solution. The major consequence of this was that in the $R$-N1-BDO- $(61,2)$ duplex there was less opening of the duplex as compared to the $S$-N1-BDO- $(61,2)$ duplex. In Figure 8, the large solvent accessible "hole" created in the major groove of the $S$-N1-BDO- $(61,2)$ duplex can be clearly observed. We speculate that the location of the vinyl group spanning the floor of the major groove in the $R$-N1-BDO- $(61,2)$ duplex somehow sterically "backstops" the incoming nucleotide triphosphate during trans-lesion replication, the lack of which might increase the propensity for incorporation of dCTP opposite the $S$-N1-BDO- $(61,2)$ lesion.

The role of stereochemistry in modulating biological processing has been established in studies of adducts arising from polycyclic aromatic hydrocarbons (55). Mao et al. (56) observed stereoselective resistance to digestion of stereoisomeric $\mathrm{N}^{2}-\mathrm{dG}$ benzo[ $[a]$ pyrene adducts by phosphodiesterases I and II. Moriya et al. demonstrated that the fidelity of translesion synthesis of such adducts depends upon chirality (57), as does mutagenic potential (58). Choi et al. $(59,60)$ noted differences in T7 polymerase processing. Likewise, Perlow et al. (61) proposed stereospecific differences for the interactions of these adducts with RNA polymerase II. Overall, stereochemistry appears to modulate the processing of adducts by a number of enzymes (62).

\section{Biological Implications}

Mutagenesis studies carried out in vivo with BD using B6c3F1 lacI transgenic mice showed point mutations at both $\mathrm{dG}$ and $\mathrm{dA}$, with approximately $20 \%$ occurring at $\mathrm{A} \bullet \mathrm{T}$ base pairs, suggesting that adenine adducts of butadiene are mutagenically significant. The observation that site-specific mutagenesis of these N1-dI adducts in both Escherichia coli (26) and in COS-7 cells (27) yielded $A \rightarrow G$ transitions was surprising because adenine-specific mutations observed in mice were primarily $\mathrm{A} \rightarrow \mathrm{T}$ transversions (63-67), although it was reported that butadiene induced $\mathrm{A} \rightarrow \mathrm{G}$ transitions in $\mathrm{H}$-ras codon 61 (68). The present results provide an attractive hypothesis as to the genesis of $\mathrm{A} \rightarrow \mathrm{G}$ mutations, i.e., that they are induced by highly mutagenic N1-(1-hydroxy-3-buten-2-yl)-2'-deoxyinosine adducts. The failure to observe high levels of $\mathrm{A} \rightarrow \mathrm{G}$ mutations in mice suggests the possibility that these adducts are not present at high levels in vivo. In this regard, it is interesting to note that the more commonly observed $\mathrm{A} \rightarrow \mathrm{T}$ mutations could be generated similarly, via incorporation of protonated dATP opposite an N1-dI adduct in the syn conformation about the glycosyl bond (Scheme 3). In this regard, the recent observation of a Hoogsteen-type pair between template dA and incoming TTP in a ternary crystal structure of the human Y-family DNA polymerase $\mathrm{t}$ is of particular interest (69), and is consistent with the notion that the pol 1 enzyme might exploit Hoogsteen-type interactions to bypass a variety of bulky DNA adducts. 


\section{Supplementary Material}

Refer to Web version on PubMed Central for supplementary material.

\section{Acknowledgements}

Dr. Jaison Jacob assisted with NMR spectroscopy and Dr. Jarrod Smith assisted with molecular modeling.

\section{References}

1. Himmelstein MW, Acquavella JF, Recio L, Medinsky MA, Bond JA. Toxicology and epidemiology of 1,3-butadiene. Crit. Rev. Toxicol 1997;27:1-108. [PubMed: 9115622]

2. Jackson MA, Stack HF, Rice JM, Waters MD. A review of the genetic and related effects of 1,3butadiene in rodents and humans. Mutat. Res 2000;463:181-213. [PubMed: 11018742]

3. Pelz N, Dempster NM, Shore PR. Analysis of low molecular weight hydrocarbons including 1,3butadiene in engine exhaust gases using an aluminum oxide porous-layer open-tubular fused-silica column. J. Chromatogr. Sci 1990;28:230-235. [PubMed: 1704381]

4. Brunnemann KD, Kagan MR, Cox JE, Hoffmann D. Analysis of 1,3-butadiene and other selected gasphase components in cigarette mainstream and sidestream smoke by gas chromatography-mass selective detection. Carcinogenesis 1990;11:1863-1868. [PubMed: 2208599]

5. Huff JE, Melnick RL, Solleveld HA, Haseman JK, Powers M, Miller RA. Multiple organ carcinogenicity of 1,3-butadiene in B6c3F1 mice after 60 weeks of inhalation exposure. Science 1985;227:548-549. [PubMed: 3966163]

6. Melnick RL, Huff J, Chou BJ, Miller RA. Carcinogenicity of 1,3-butadiene in C57BL/6 x C3H F1 mice at low exposure concentrations. Cancer Res 1990;50:6592-6599. [PubMed: 2208121]

7. Melnick RL, Huff JE, Roycroft JH, Chou BJ, Miller RA. Inhalation toxicology and carcinogenicity of 1,3-butadiene in B6c3F1 mice following 65 weeks of exposure. Environ. Health Perspect 1990;86:2736. [PubMed: 2401263]

8. Owen PE, Glaister JR. Inhalation toxicity and carcinogenicity of 1,3-butadiene in sprague- dawley rats. Environ. Health Perspect 1990;86:19-25. [PubMed: 2401255]

9. United States Environmental Protection Agency. 1,3-Butadiene. Carcinogenicity assessment for lifetime exposure: Weight-of-evidence characterization. 2002. available at http://www.epa.gov/iris/subst/0139.htm.

10. International Agency for Research on Cancer. Re-evaluation of some organic chemicals, hydrazine and hydrogen peroxide, IRC Monographs on the Evaluation of Carcinogenic Risks to Humans. IARC Sci. Publ 1999;71:109-125.

11. Ward JB Jr, Ammenheuser MM, Bechtold WE, Whorton EB Jr, Legator MS. hprt mutant lymphocyte frequencies in workers at a 1,3-butadiene production plant. Environ. Health Perspect 1994;102:7985. [PubMed: 7698091]

12. Ward JB Jr, Ammenheuser MM, Whorton EB Jr, Bechtold WE, Kelsey KT, Legator MS. Biological monitoring for mutagenic effects of occupational exposure to butadiene. Toxicology 1996;113:8490. [PubMed: 8901886]

13. Sram RJ, Rossner P, Peltonen K, Podrazilova K, Mrackova G, Demopoulos NA, Stephanou G, Vlachodimitropoulos D, Darroudi F, Tates AD. Chromosomal aberrations, sister-chromatid exchanges, cells with high frequency of SCE, micronuclei and comet assay parameters in 1,3butadiene-exposed workers. Mutat. Res 1998;419:145-154. [PubMed: 9804932]

14. Delzell E, Sathiakumar N, Hovinga M, Macaluso M, Julian J, Larson R, Cole P, Muir DC. A followup study of synthetic rubber workers. Toxicology 1996;113:182-189. [PubMed: 8901897]

15. Meinhardt TJ, Lemen RA, Crandall MS, Young RJ. Environmental epidemiologic investigation of the styrene-butadiene rubber industry. Mortality patterns with discussion of the hematopoietic and lymphatic malignancies. Scand. J. Work Environ. Health 1982;8:250-259. [PubMed: 7170621]

16. Matanoski G, Francis M, Correa-Villasenor A, Elliott E, Santos-Burgoa C, Schwartz L. Cancer epidemiology among styrene-butadiene rubber workers. IARC Sci. Publ 1993;127:363-374. [PubMed: 8070882] 
17. Santos-Burgoa C, Matanoski GM, Zeger S, Schwartz L. Lymphohematopoietic cancer in styrenebutadiene polymerization workers. Am. J. Epidemiol 1992;136:843-854. [PubMed: 1442750][see comments].

18. Macaluso M, Larson R, Delzell E, Sathiakumar N, Hovinga M, Julian J, Muir D, Cole P. Leukemia and cumulative exposure to butadiene, styrene and benzene among workers in the synthetic rubber industry. Toxicology 1996;113:190-202. [PubMed: 8901898]

19. Matanoski GM, Schwartz L. Mortality of workers in styrene-butadiene polymer production. J. Occup. Med 1987;29:675-680. [PubMed: 3655951]

20. Santos-Burgoa C, Eden-Wynter RA, Riojas-Rodriguez H, Matanoski GM. Living in a chemical world. Health impact of 1,3-butadiene carcinogenesis. Ann. N. Y. Acad. Sci 1997;837:176-188. [PubMed: 9472340]

21. Matanoski G, Elliott E, Tao X, Francis M, Correa-Villasenor A, Santos-Burgoa C. Lymphohematopoietic cancers and butadiene and styrene exposure in synthetic rubber manufacture. Ann. N. Y. Acad. Sci 1997;837:157-169. [PubMed: 9472338]

22. Albertini R, Clewell H, Himmelstein MW, Morinello E, Olin S, Preston J, Scarano L, Smith MT, Swenberg J, Tice R, Travis C. The use of non-tumor data in cancer risk assessment: Reflections on butadiene, vinyl chloride, and benzene. Regul. Toxicol. Pharmacol 2003;37:105-132. [PubMed: 12662914]

23. Csanady GA, Guengerich FP, Bond JA. Comparison of the biotransformation of 1,3-butadiene and its metabolite, butadiene monoepoxide, by hepatic and pulmonary tissues from humans, rats and mice [published erratum appears in Carcinogenesis 1993 Apr;14(4):784]. Carcinogenesis 1992;13:11431153. [PubMed: 1638680]

24. Duescher RJ, Elfarra AA. Human liver microsomes are efficient catalysts of 1,3-butadiene oxidation: evidence for major roles by cytochromes P450 2A6 and 2E1. Arch. Biochem. Biophys 1994;311:342349. [PubMed: 8203896]

25. Selzer RR, Elfarra AA. Characterization of N1- and $\mathrm{N}^{6}$-adenosine adducts and N1-inosine adducts formed by the reaction of butadiene monoxide with adenosine: Evidence for the N1-adenosine adducts as major initial products. Chem. Res. Toxicol 1996;9:875-881. [PubMed: 8828924]

26. Rodriguez DA, Kowalczyk A, Ward JBJ, Harris CM, Harris TM, Lloyd RS. Point mutations induced by 1,2-epoxy-3-butene N1 deoxyinosine adducts. Environ. Mol. Mutagen 2001;38:292-296. [PubMed: 11774359]

27. Kanuri M, Nechev LV, Tamura PJ, Harris CM, Harris TM, Lloyd RS. Mutagenic spectrum of butadiene-derived N1-deoxyinosine adducts and $\mathrm{N}^{6}, \mathrm{~N}^{6}$-deoxyadenosine intrastrand cross-links in mammalian cells. Chem. Res. Toxicol 2002;15:1572-1580. [PubMed: 12482239]

28. Scholdberg TA, Merritt WK, Dean SM, Kowalczyk A, Harris CM, Harris Tm, Lloyd RS, Stone MP. Structure of an oligodeoxynucleotide containing a butadiene oxide-Derived N1-hydroxyalkyl deoxyinosine adduct in the human $N$-ras codon 61 sequence. Biochemistry 2005;44in press.

29. Schmitz U, James TL. How to generate accurate solution structures of double-helical nucleic acid fragments using nuclear magnetic resonance and restrained molecular dynamics. Meth. Enzymol 1995;261:3-44. [PubMed: 8569500]

30. Borer, PN. Handbook of Biochemistry and Molecular Biology. Cleveland, OH: CRC Press; 1975.

31. Feng B, Stone MP. Solution structure of an oligodeoxynucleotide containing the human $N$-ras codon 61 sequence refined from ${ }^{1} \mathrm{H}$ NMR using molecular dynamics restrained by nuclear Overhauser effects. Chem. Res. Toxicol 1995;8:821-832. [PubMed: 7492731]

32. Piotto M, Saudek V, Sklenar V. Gradient-tailored excitation for single-quantum NMR spectroscopy of aqueous solutions. J. Biomol. NMR 1992;2:661-665. [PubMed: 1490109]

33. James TL. Relaxation matrix analysis of two-dimensional nuclear Overhauser effect spectra. Curr. Opin. Struct. Biol 1991;1:1042-1053.

34. Keepers JW, James TL. A theoretical study of distance determination from NMR. Two-dimensional nuclear Overhauser effect spectra. J. Magn. Reson 1984;57:404-426.

35. Borgias BA, James TL. Two-dimensional nuclear Overhauser effect: Complete relaxation matrix analysis. Meth. Enzymol 1989;176:169-183. [PubMed: 2811685]

36. Borgias BA, James TL. MARDIGRAS--a procedure for matrix analysis of relaxation for discerning geometry of an aqueous structure. J. Magn. Reson 1990;87:475-487. 
37. Liu H, Spielmann HP, Ulyanov NB, Wemmer DE, James TL. Interproton distance bounds from 2D NOE intensities: effect of experimental noise and peak integration errors. J. Biomol. NMR 1995;6:390-402. [PubMed: 8563467]

38. Wang H, Zuiderweg ERP, Glick GD. Solution structure of a disulfide cross-linked DNA hairpin. J. Am. Chem. Soc 1995;117:2981-2991.

39. Geen H, Freeman R. Band-selective radiofrequency pulses. J. Magn. Reson 1991;93:93-141.

40. Lankhorst PP, Haasnoot AG, Erkelens C, Altona C. Carbon-13 NMR in conformational analysis of nucleic acid fragments. 3. The magnitude of torsional angle in $\mathrm{d}(\mathrm{TpA})$ from CCOP and HCOP NMR coupling constants. Nucleic Acids Res 1984;12:5419-5428. [PubMed: 6087285]

41. Arnott S, Hukins DWL. Optimised parameters for A-DNA and B-DNA. Biochem. Biophys. Res. Comm 1972;47:1504-1509. [PubMed: 5040245]

42. Case, DA.; Pearlman, DA.; Caldwell, JW.; Cheatham, TE., III; Wang, J.; Ross, WS.; Simmerling, CL.; Darden, TA.; Merz, KM.; Stanton, RV.; Cheng, AL.; Vincent, JJ.; Crowley, M.; Tsui, V.; Gohlke, H.; Radmer, RJ.; Duan, Y.; Pitera, J.; Massova, I.; Seibel, GL.; Singh, UC.; Weiner, PK.; Kollman, PA. AMBER 7.0. San Francisco, CA: University of California; 2002.

43. Clore GM, Brunger AT, Karplus M, Gronenborn AM. Application of olecular dynamics with interproton distance restraints to three-dimensional protein structure determination. J. Mol. Biol 1986;191:523-551. [PubMed: 3029386]

44. Ryckaert J-P, Ciccotti G, Berendsen HJC. Numerical integration of the cartesian equations of motion of a system with constraints: Molecular dynamics of n-alkanes. J. Comp. Phys 1977;23:327-341.

45. Bashford D, Case DA. Generalized Born models of macromolecular solvation effects. Ann. Rev. Phys. Chem 2000;51:129-152. [PubMed: 11031278]

46. Tsui V, Case DA. Theory and applications of the generalized Born solvation model in macromolecular simulations. Biopolymers 2000;56:275-291. [PubMed: 11754341]

47. Cornell WD, Cieplak P, Bayly CI, Gould IR, Merz KM, Ferguson DM, Spellmeyer DC, Fox T, Caldwell JW, Kollman PA. A second generation force field for the simulation of proteins, nucleic acids, and organic molecules. J. Am. Chem. Soc 1995;117:5179.

48. Keepers J, Kollman PA, James TL. Molecular mechanical studies of base-pair opening in d (CGCGC):d(GCGCG), $\mathrm{dG}_{5}: \mathrm{dC}_{5}, \mathrm{~d}$ (TATAT):d(ATATA), and $\mathrm{dA}_{5}: \mathrm{dT}_{5}$ in the $\mathrm{B}$ and $\mathrm{Z}$ forms of DNA. Biopolymers 1984;23:2499-2511. [PubMed: 6518264]

49. Lu XJ, Olson WK. 3DNA: A software package for the analysis, rebuilding and visualization of threedimensional nucleic acid structures. Nucleic Acids Res 2003;31:5108-5121. [PubMed: 12930962]

50. Kowalczyk A, Harris CM, Harris TM. Synthesis and characterization of oligodeoxynucleotides containing an N1 beta-hydroxyalkyl adduct of 2'-deoxyinosine. Chem. Res. Toxicol 2001;14:746753. [PubMed: 11409946]

51. Patel DJ, Shapiro L, Hare D. DNA and RNA: NMR studies of conformations and dynamics in solution. Q. Rev. Biophys 1987;20:35-112. [PubMed: 2448843]

52. Reid BR. Sequence-specific assignments and their use in NMR studies of DNA structure. Q. Rev. Biophys 1987;20:2-28.

53. Weisz K, Shafer RH, Egan W, James TL. Solution structure of the octamer motif in immunoglobulin genes via restrained molecular dynamics calculations. Biochemistry 1994;33:354-366. [PubMed: 8286357]

54. Nikonowicz EP, Gorenstein DG. Two-dimensional ${ }^{1} \mathrm{H}$ and ${ }^{31} \mathrm{P}$ NMR spectra and restrained molecular dynamics structure of a mismatched GA decamer oligodeoxyribonucleotide duplex. Biochemistry 1990;29:8845-8858. [PubMed: 2271561]

55. Geacintov NE, Cosman M, Hingerty BE, Amin S, Broyde S, Patel DJ. NMR solution structures of stereoisomeric covalent polycyclic aromatic carcinogen-DNA adducts: Principles, Patterns and diversity. Chem. Res. Toxicol 1997;10:111-146. [PubMed: 9049424]

56. Mao B, Li B, Amin S, Cosman M, Geacintov NE. Opposite stereoselective resistance to digestion by phosphodiesterases I and II of benzo[ $a]$ pyrene diol epoxide-modified oligonucleotide adducts. Biochemistry 1993;32:11785-11793. [PubMed: 8218249]

57. Moriya M, Spiegel S, Fernandes A, Amin S, Liu T, Geacintov N, Grollman AP. Fidelity of translesional synthesis past benzo[ $[a]$ pyrene diol epoxide-2'-deoxyguanosine DNA adducts: Marked 
effects of host cell, sequence context, and chirality. Biochemistry 1996;35:16646-16651. [PubMed: 8988000]

58. Fernandes A, Liu T, Amin S, Geacintov NE, Grollman AP, Moriya M. Mutagenic potential of stereoisomeric bay region (+)- and (-)-cis-anti-benzo[a]pyrene diol epoxide- $\mathrm{N}^{2}-2^{\prime}$-deoxyguanosine adducts in Escherichia coli and simian kidney cells. Biochemistry 1998;37:10164-10172. [PubMed: 9665722]

59. Choi DJ, Marino-Alessandri DJ, Geacintov NE, Scicchitano DA. Site-specific benzo[a]pyrene diol epoxide-DNA adducts inhibit transcription elongation by bacteriophage T7 RNA polymerase. Biochemistry 1994;33:780-787. [PubMed: 8292606]

60. Choi DJRR, Liu T, Geacintov NE, Scicchitano DA. Incorrect base insertion and prematurely terminated transcripts during T7 RNA polymerase transcription elongation past benzo[ $a]$ pyrenediol epoxide-modified DNA. J. Mol. Biol 1996;264:213-219. [PubMed: 8951371]

61. Perlow RAKA, Hingerty BE, Geacintov NE, Broyde S, Scicchitano DA. DNA adducts from a tumorigenic metabolite of benzo[ $a]$ pyrene block human RNA polymerase II elongation in a sequence- and stereochemistry-dependent manner. J. Mol. Biol 2002;321:29-47. [PubMed: 12139931]

62. Shukla R, Jelinsky S, Liu T, Geacintov NE, Loechler EL. How stereochemistry affects mutagenesis by $\mathrm{N}^{2}$-deoxyguanosine adducts of 7,8-dihydroxy-9,10-epoxy-7,8,9,10-tetrahydrobenzo[ $\left.a\right]$ pyrene:

Configuration of the adduct bond is more important than those of the hydroxyl groups. Biochemistry 1997;36:13263-13269. [PubMed: 9341216]

63. Recio L, Saranko CJ, Steen AM. 1,3-butadiene: Cancer, mutations, and adducts. Part II: Roles of two metabolites of 1,3-butadiene in mediating its in vivo genotoxicity. Res. Rep. Health Eff. Inst 2000:4987. [PubMed: 10925839]discussion 141-149.

64. Recio L, Steen AM, Pluta LJ, Meyer KG, Saranko CJ. Mutational spectrum of 1,3-butadiene and metabolites 1,2-epoxybutene and 1,2:3,4-diepoxybutane to assess mutagenic mechanisms. Chem. Biol. Interact 2001;135-136:325-341.

65. Sisk SC, Pluta LJ, Bond JA, Recio L. Molecular analysis of lacI mutants from bone marrow of B6c3F1 transgenic mice following inhalation exposure to 1,3-butadiene. Carcinogenesis 1994;15:471-477. [PubMed: 8118931]

66. Recio L, Meyer KG. Increased frequency of mutations at A:T base pairs in the bone marrow of B6c3F1 laci transgenic mice exposed to 1,3-butadiene. Environ. Mol. Mutagen 1995;26:1-8. [PubMed: 7641703]

67. Steen AM, Meyer KG, Recio L. Analysis of hprt mutations occurring in human TK6 lymphoblastoid cells following exposure to 1,2:3,4-diepoxybutane. Mutagenesis 1997;12:61-67. [PubMed: 9106245]

68. Goodrow TL, Nichols WW, Storer RD, Anderson MW, Maronpot RR. Activation of H-ras is prevalent in 1,3-butadiene-induced and spontaneously occurring murine Harderian gland tumors. Carcinogenesis 1994;15:2665-2667. [PubMed: 7955123]

69. Nair DT, Johnson RE, Prakash S, Prakash L, Aggarwal AK. Replication by human DNA polymerase 1 occurs by Hoogsteen base-pairing. Nature 2004;430:377-380. [PubMed: 15254543] 
A

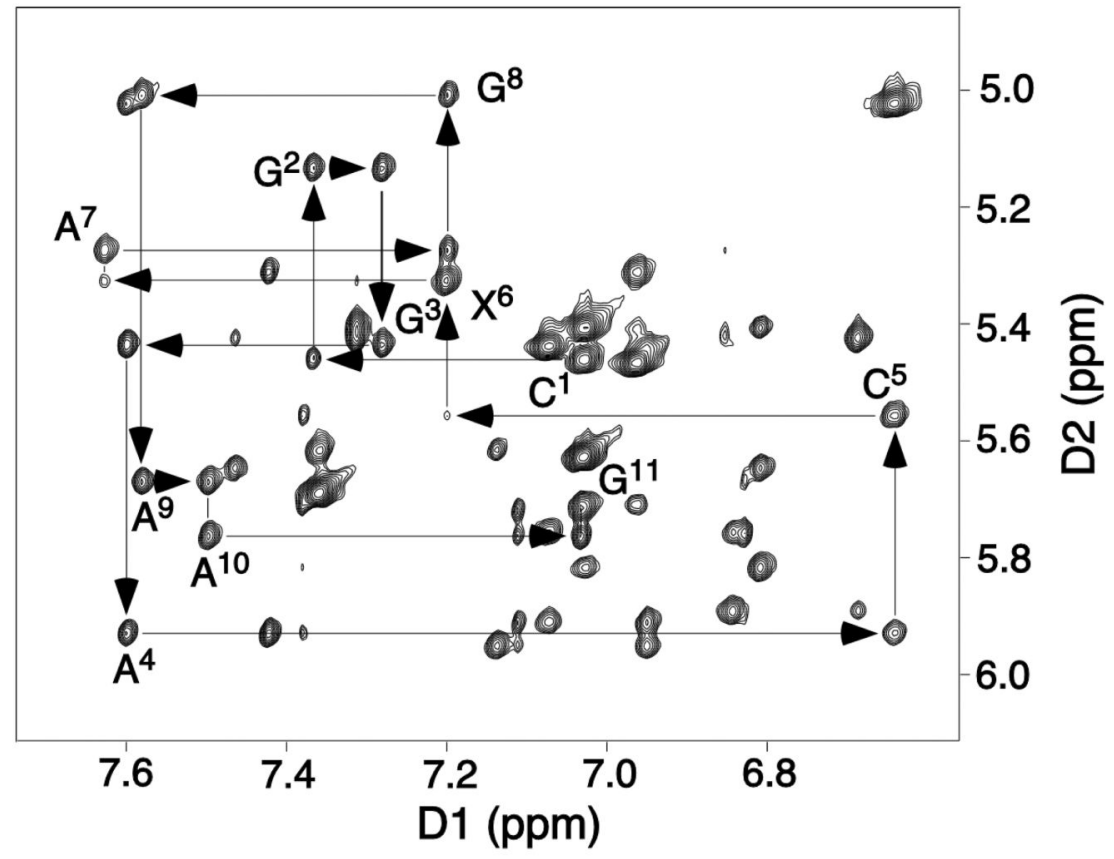

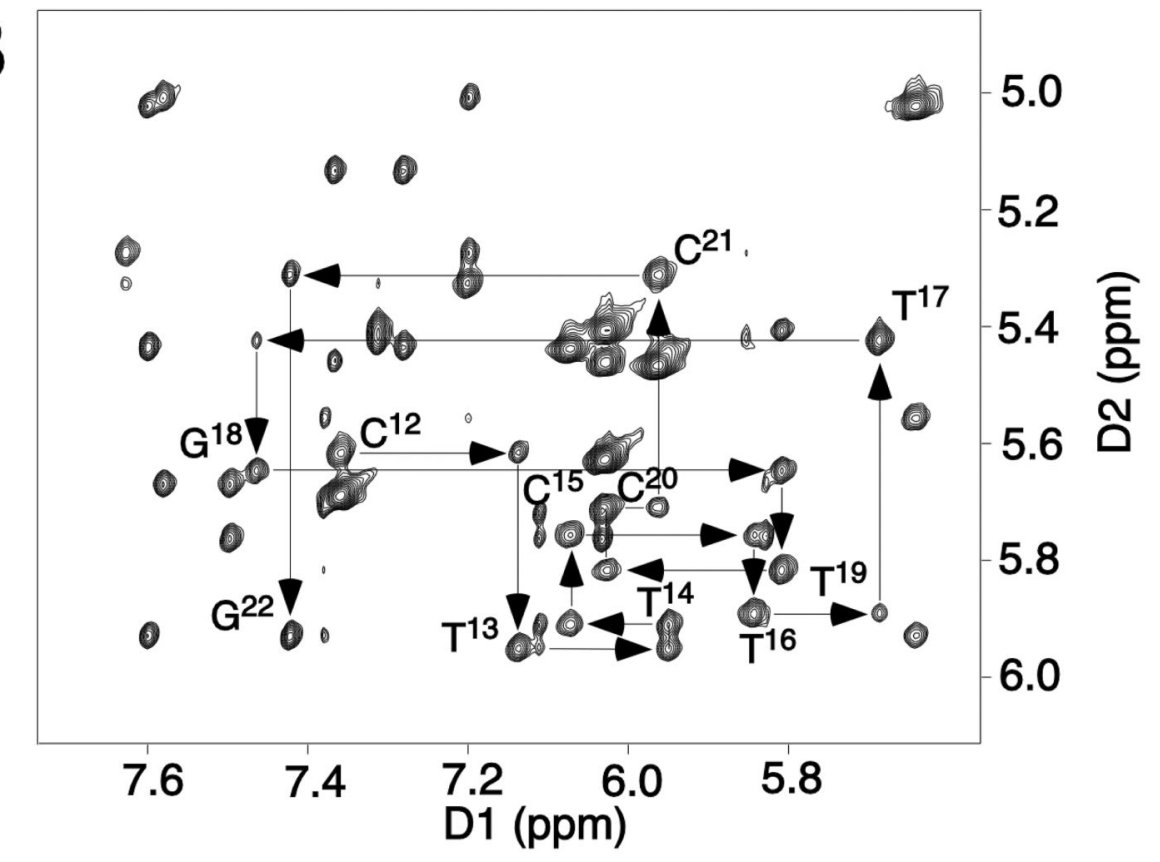

Figure 1.

Expanded plots of a NOESY spectrum at a mixing time of $200 \mathrm{~ms}$ showing sequential NOE connectivities from aromatic to anomeric protons. A. Nucleotides $\mathrm{C}^{1} \rightarrow \mathrm{G}^{11}$ of the modified strand of the $R$-N1-BDO- $(61,2)$ adduct. B. Nucleotides $\mathrm{C}^{12} \rightarrow \mathrm{G}^{22}$ of the $R$-N1-BDO- $(61,2)$ adduct. The experiment was at $800.23 \mathrm{MHz}$ and $25^{\circ} \mathrm{C}$. 


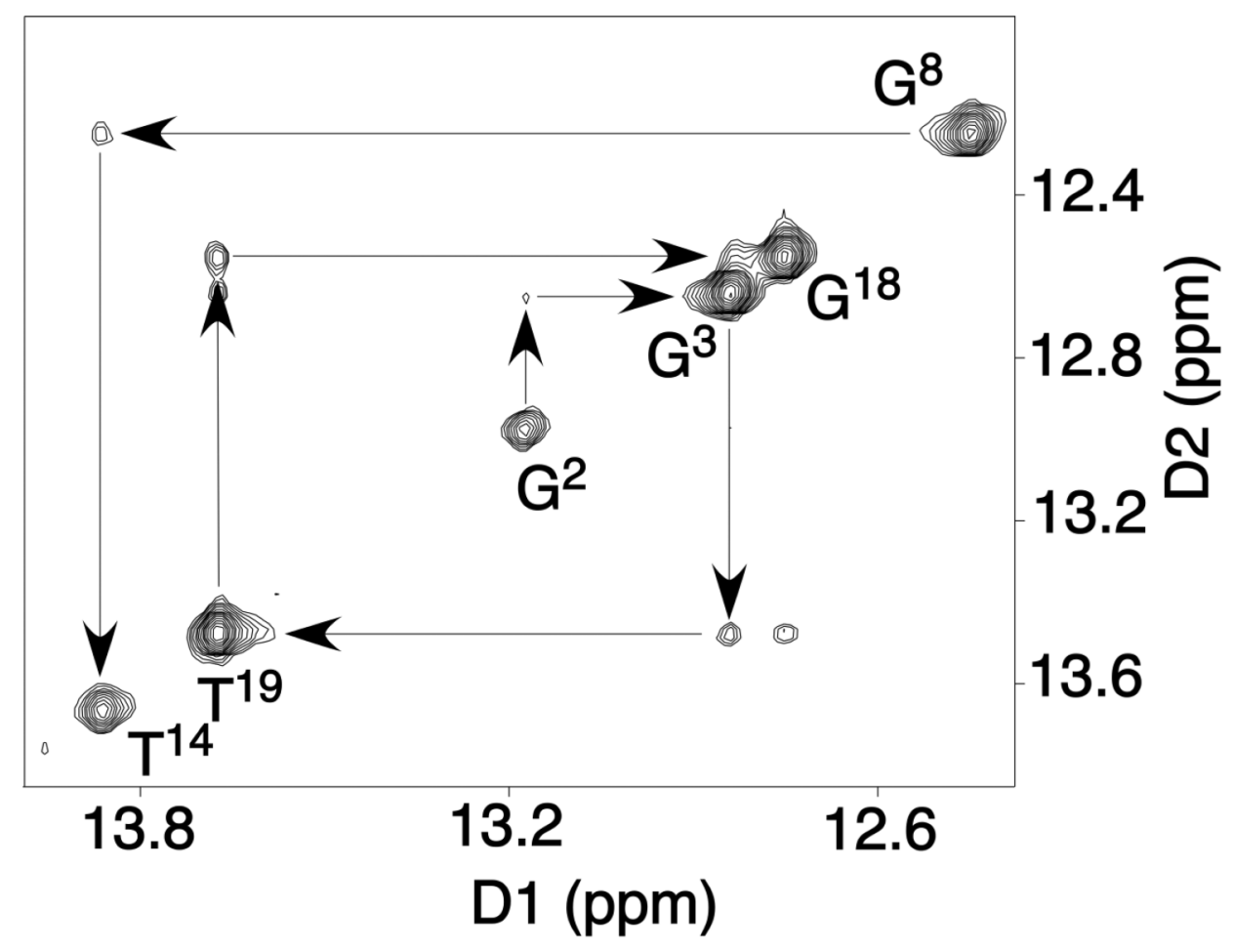

Figure 2.

Expanded plot of a NOESY spectrum at a mixing time of $200 \mathrm{~ms}$ showing NOE connectivities for the imino protons for the base pairs from $G^{2} \cdot C^{21}$ to $A^{10} \bullet T^{13}$. There were no imino resonances observed for base pairs $\mathrm{X}^{6} \cdot \mathrm{T}^{17}$ and $\mathrm{A}^{7} \cdot \mathrm{T}^{16}$. The experiment was at $800.23 \mathrm{MHz}$ and $25^{\circ} \mathrm{C}$. 


\section{NOEs to Major Groove Protons}

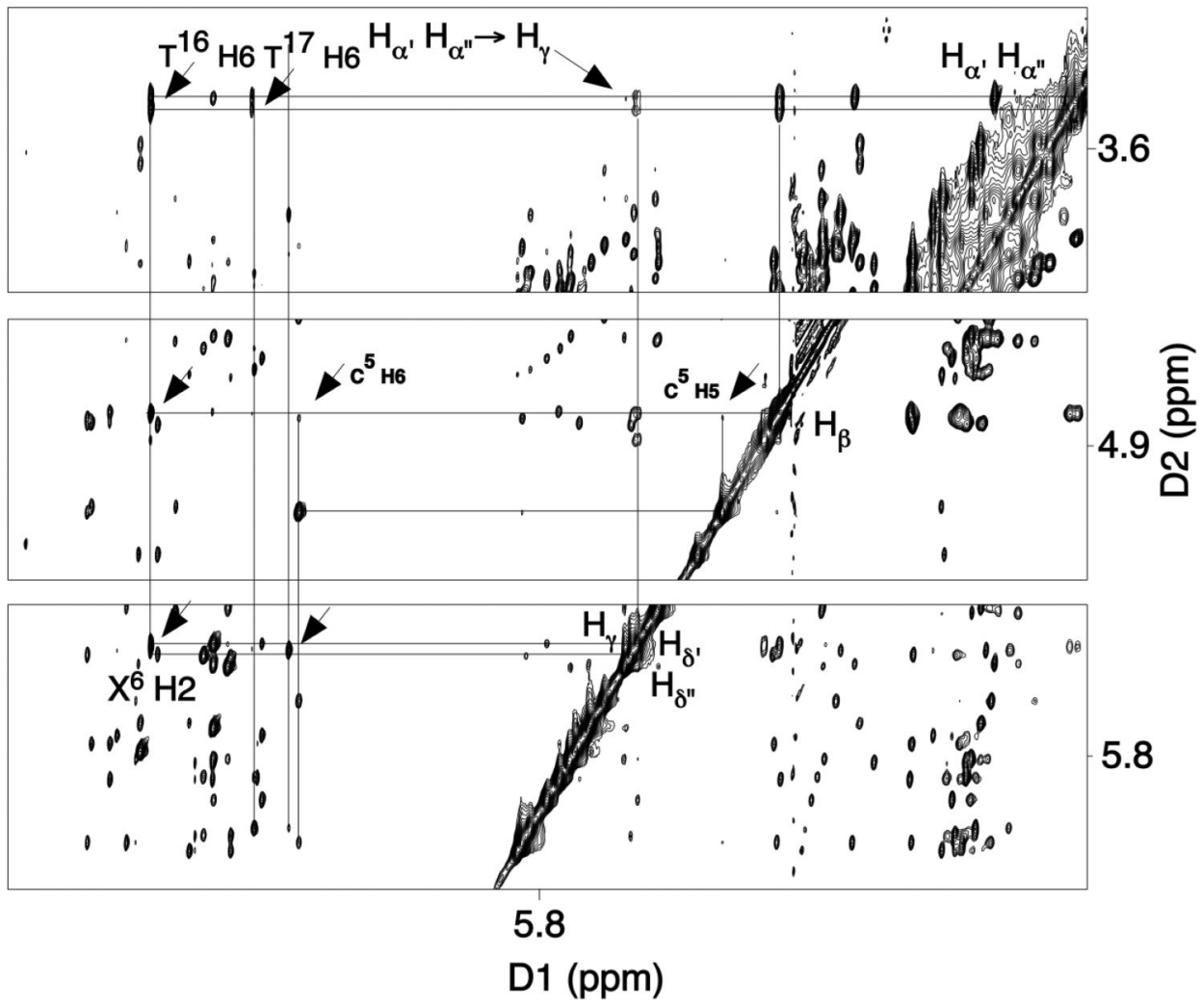

Figure 3.

Expanded NOESY spectrum at $200 \mathrm{~ms}$ mixing time exhibiting the assignment of adduct protons in the $R$-N1-BDO- $(61,2)$ duplex. The experiment was at $800.23 \mathrm{MHz}$ and $25^{\circ} \mathrm{C}$. 


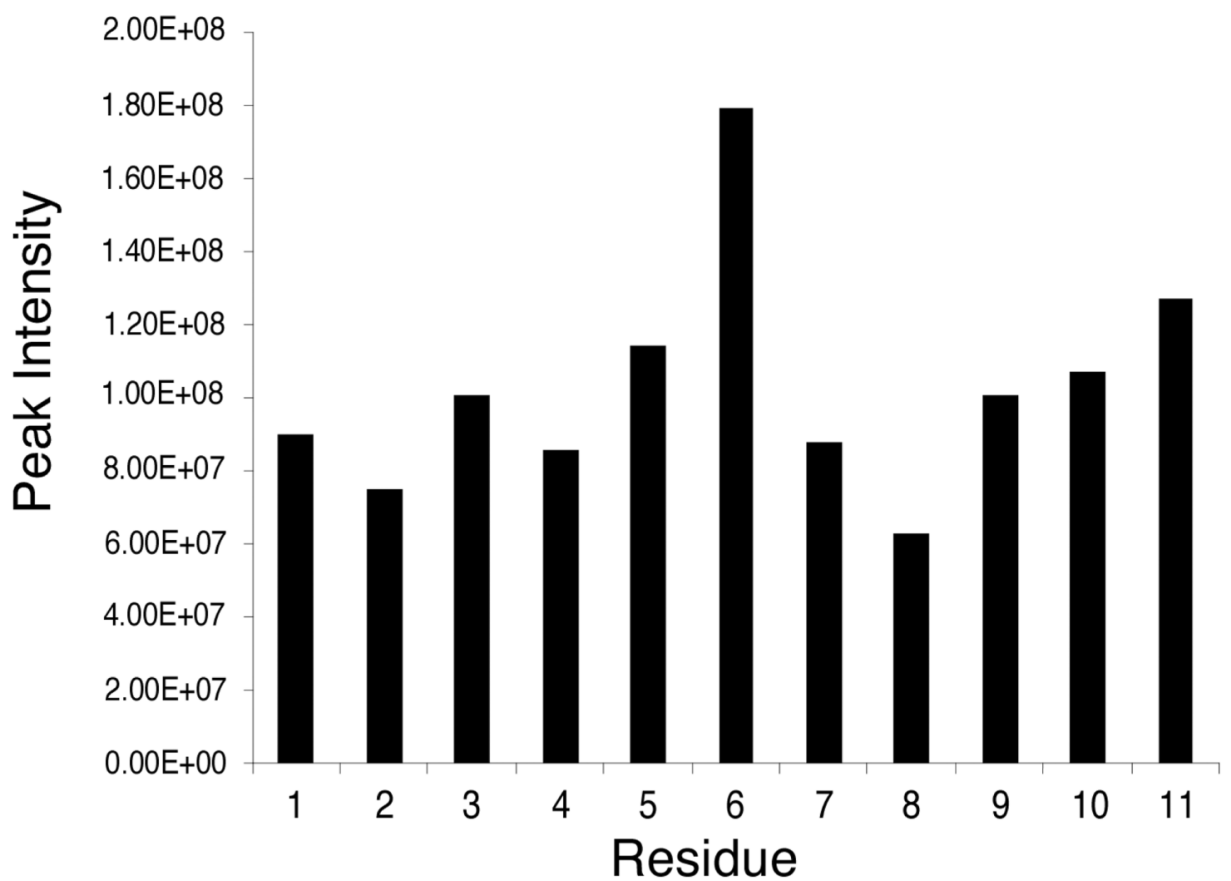

Figure 4.

Resonance intensities of intranucleotide $\mathrm{H} 1^{\prime}$ and $\mathrm{H} 6 / \mathrm{H} 81 \mathrm{H}$ NOE crosspeaks at $800.13 \mathrm{MHz}$ and $35^{\circ} \mathrm{C}$. 

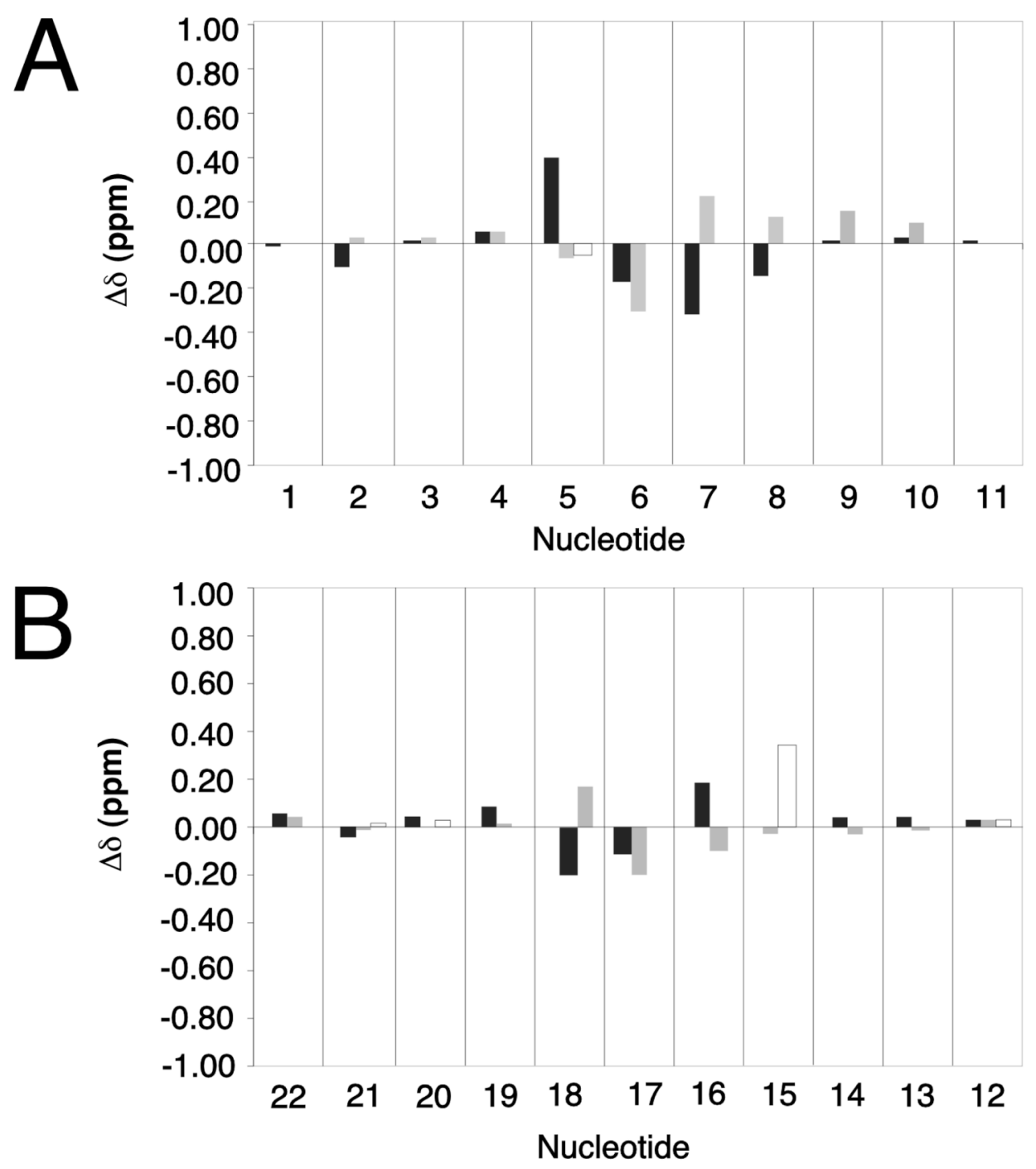

Figure 5.

Chemical shift differences of protons of the $R$-N1-BDO- $(61,2)$ adduct duplex relative to the unmodified ras61 oligodeoxynucleotide. A. The modified strand of the $R$-N1-BDO- $(61,2)$ adduct. B. The complementary strand of the $R-\mathrm{N} 1-\mathrm{BDO}-(61,2)$ adduct. Grey bars represent the deoxyribose $\mathrm{H} 1$ ' protons; black bars represent the purine $\mathrm{H} 8$ or pyrimidine $\mathrm{H} 6$ protons, respectively. 

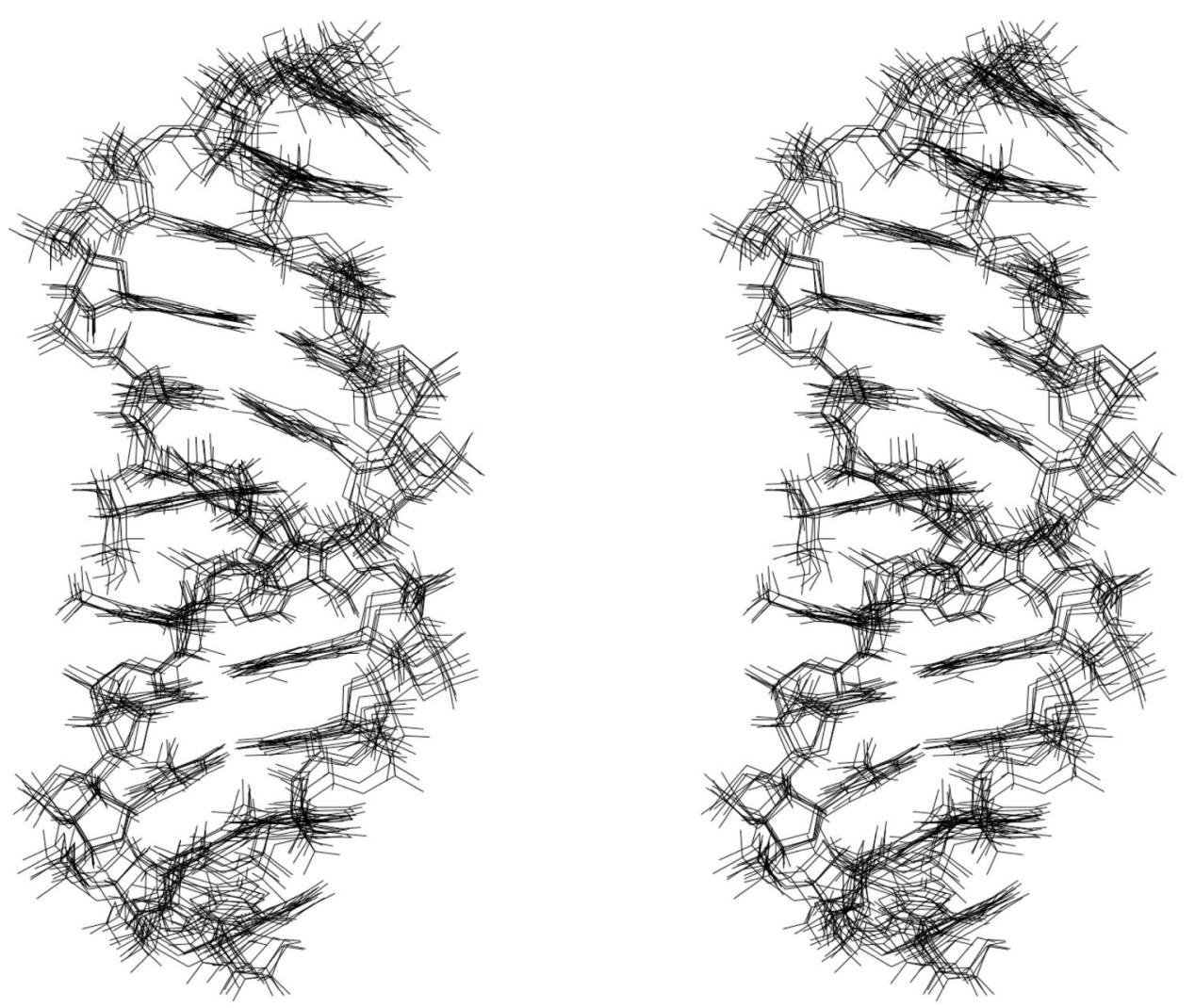

Figure 6.

A stereoview of superimposed structures emergent from the simulated annealing rMD protocol; the structures resulted from randomly seeded calculations. 


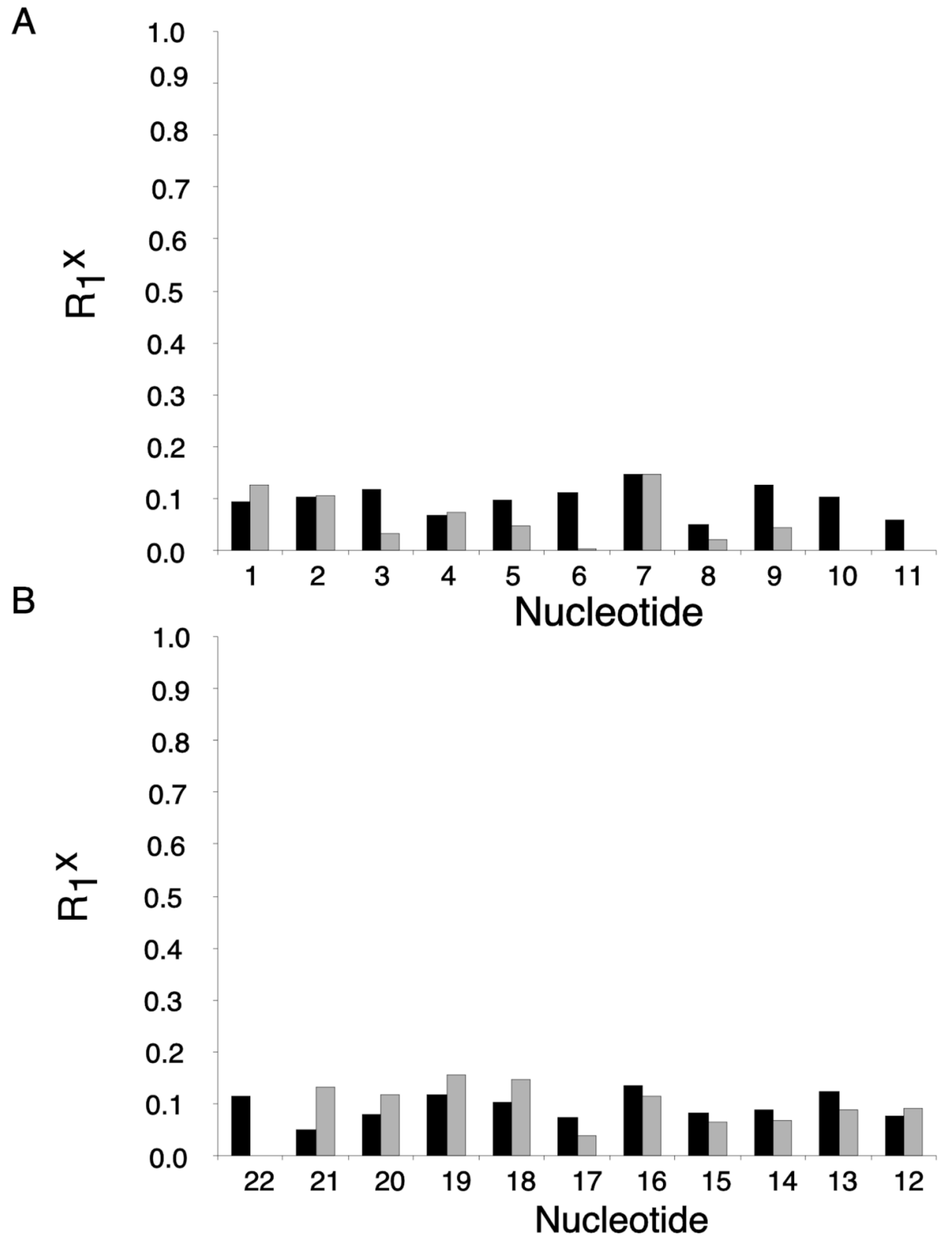

Figure 7.

Distribution of sixth root residual $\left(\mathrm{R}_{\mathrm{x}}{ }_{\mathrm{x}}\right)$ values calculated using CORMA. A. the modified strand of the $R$-N1-BDO- $(61,2)$ duplex. B. the complementary strand of the $R$-N1-BDO- $(61,2)$ duplex. The dark bars represent intranucleotide $\mathrm{R}_{\mathrm{x}}^{1}$ values. The light bars represent internucleotide $\mathrm{R}_{\mathrm{x}}^{1}$ values. 


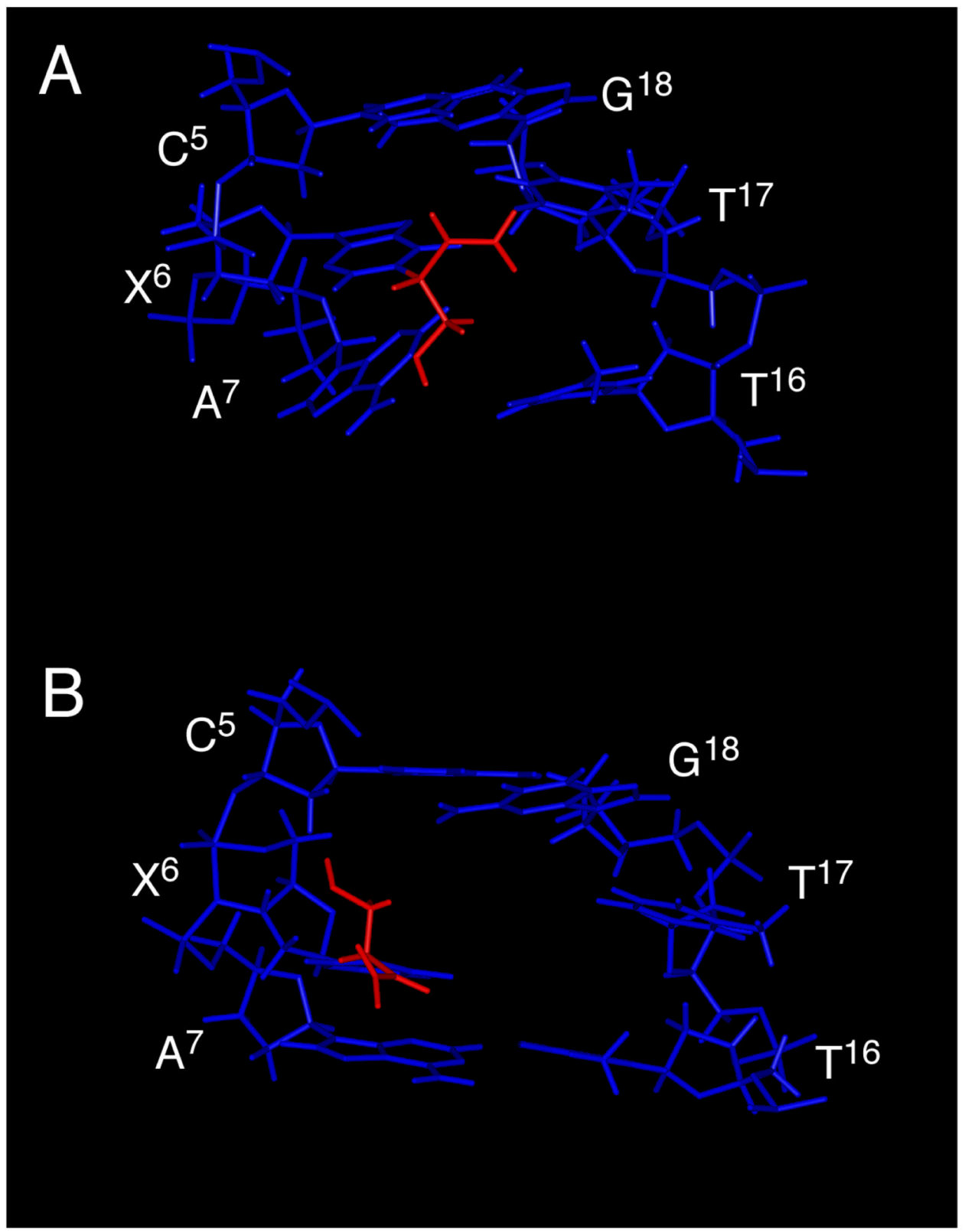

Figure 8.

A. $R$-N1-BDO- $(61,2)$ Adduct: View from the major groove of $\mathrm{X}^{6} \bullet \mathrm{T}^{17}$ and the surrounding base pairs $\mathrm{C}^{5} \cdot \mathrm{G}^{18}, \mathrm{~A}^{7} \cdot \mathrm{T}^{16}$ and $\mathrm{G}^{8} \cdot \mathrm{C}^{15}$. B. $S$-N1-BDO- $(61,2)$ Adduct: View from the major groove of $X^{6} \cdot T^{17}$ and the surrounding base pairs $C^{5} \cdot G^{18}, A^{7} \cdot T^{16}$ and $G^{8} \cdot C^{15}$. In both instances the duplex DNA is shown in blue, the BD moiety is in red. 


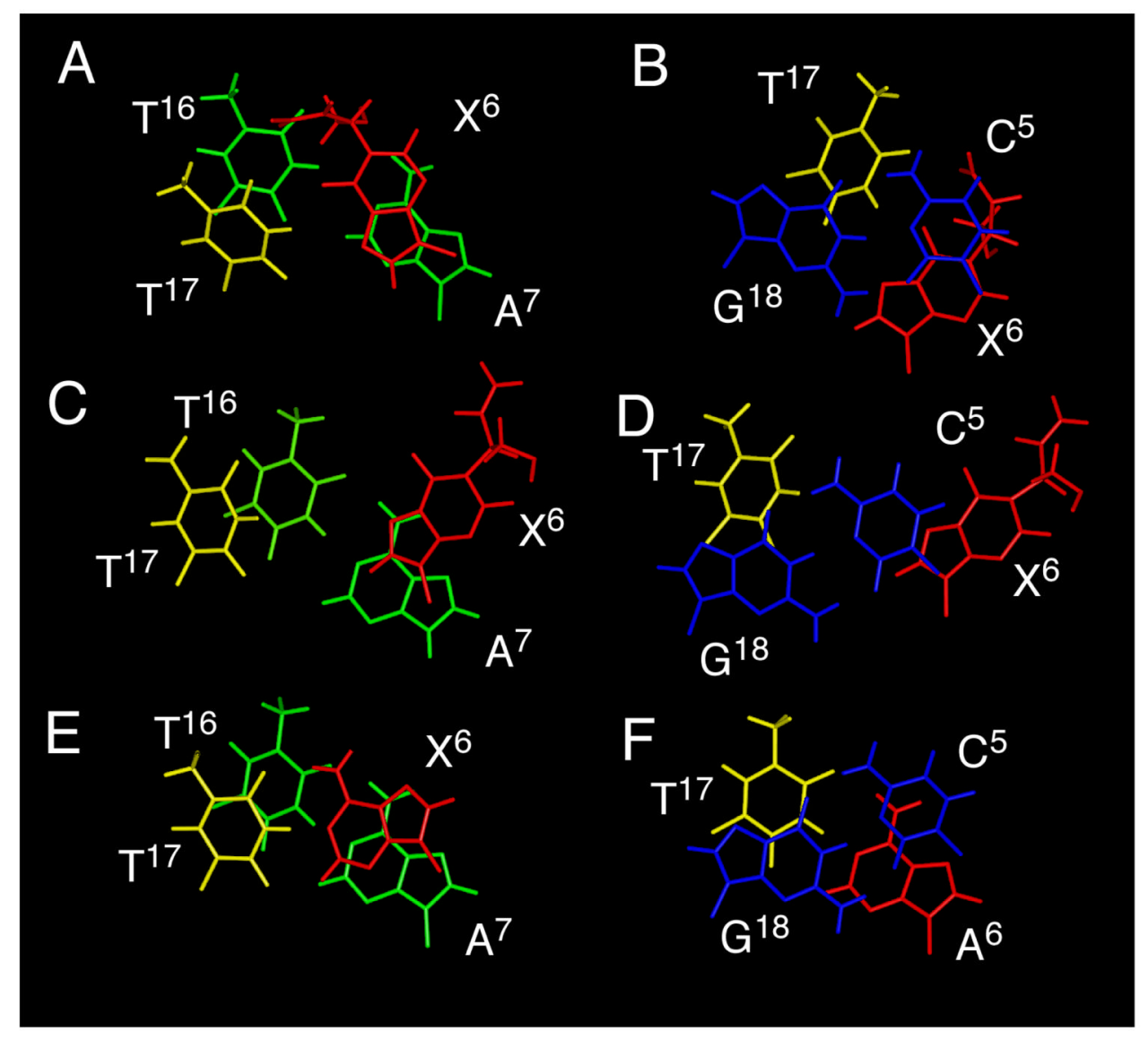

Figure 9.

Base stacking orientations of the $R$-N1-BDO- $(61,2)$ duplex and the $S$-N1-BDO- $(61,2)$ duplexes at the lesion site as predicted by rMD calculations, as compared to the unmodified ras 61 oligodeoxynucleotide duplex. A. The $R$-N1-BDO- $(61,2)$ duplex detailing base stacking of the $\mathrm{X}^{6}$ and $\mathrm{A}^{7}$ base pairs. B. The $R-\mathrm{N} 1-\mathrm{BDO}-(61,2)$ duplex detailing base stacking of the $\mathrm{C}^{5}$ and $\mathrm{X}^{6}$ base pairs. C. The modified $S$-N1-BDO- $(61,2)$ duplex detailing base stacking of the $\mathrm{X}^{6}$ and $\mathrm{A}^{7}$ base pairs. D. The $S$-N1-BDO- $(61,2)$ duplex detailing base stacking of the $\mathrm{C}^{5}$ and $\mathrm{X}^{6}$ base pairs. E. The unmodified ras61 oligodeoxynucleotide duplex detailing base stacking of the $\mathrm{A}^{6}$ and $\mathrm{A}^{7}$ base pairs. F. The unmodified ras 61 oligodeoxynucleotide duplex detailing base stacking of the $\mathrm{C}^{5}$ and $\mathrm{A}^{6}$ base pairs. 


\section{A}

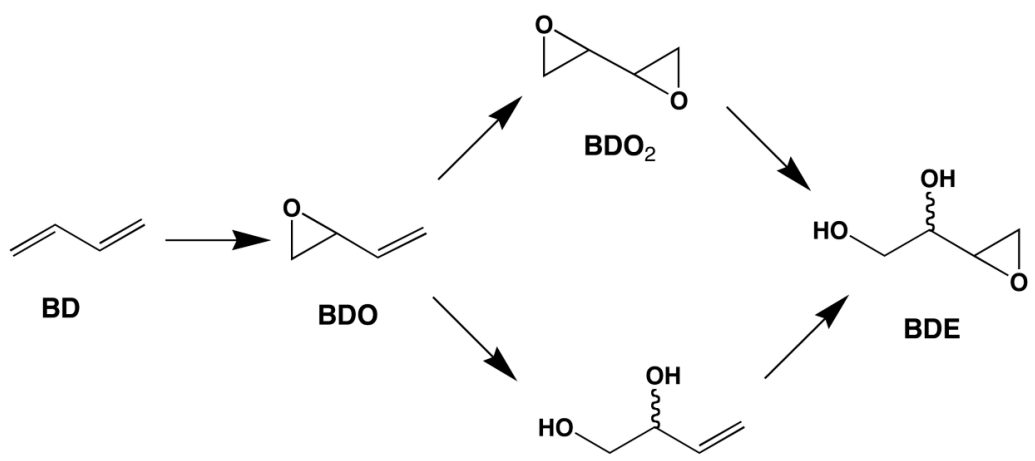

B

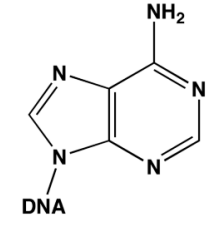

Deoxyadenosine in DNA

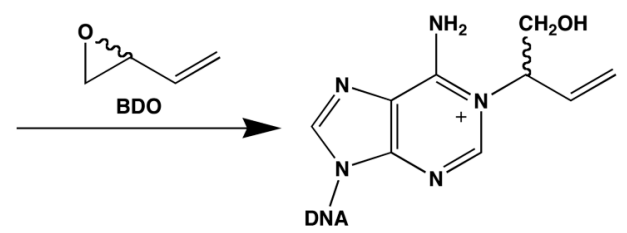

N1-(1-hydroxy-3-buten-2-yl)-2'-deoxyadenosine adduct<smiles>C=CC(CO)n1cnc2c(ncn2[N+](=O)[O-])c1=O</smiles>

N1-(1-hydroxy-3-buten-2-yl)-2'-deoxyinosine adduct

Scheme 1.

A. Cytochrome P450-Mediated Epoxidation of Butadiene to Mono- and Di-Epoxides. B. Alkylation of Deoxyadenosine $\mathrm{N} 1$ by $\mathrm{C}_{\beta}$ of Butadiene Mono-Epoxide (BDO) and Subsequent Deamination Yields the N1-(1-hydroxy-3-buten-2-yl)-2'-Deoxyinosine Adduct. 
A.

$$
\begin{gathered}
\underline{60} \underline{61} \underline{62} \\
5^{\prime}-C^{1}\left|G^{2} G^{3} A^{4}\right| C^{5} X^{6} A^{7}\left|G^{8} A^{9} A^{10}\right| G^{11}-3^{\prime} \\
3^{\prime}-G^{22}\left|C^{21} C^{20} T^{19}\right| G^{18} T^{17} T^{16}\left|C^{15} T^{14} T^{13}\right| C^{12}-5^{\prime}
\end{gathered}
$$

B.

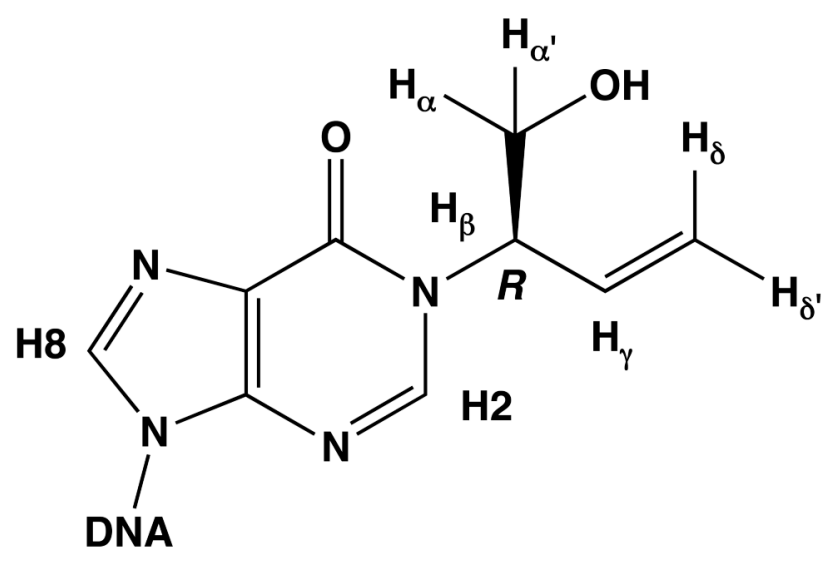

N1-(1-Hydroxy-3-buten-2(R)-yl)-2'-deoxyinosine Adduct

Scheme 2.

A. The ras61 oligodeoxynucleotide. B. The chemical structures of the N1-(1-hydroxy-3butene-2(R)-yl)-2'-deoxyinosine adduct. 
A
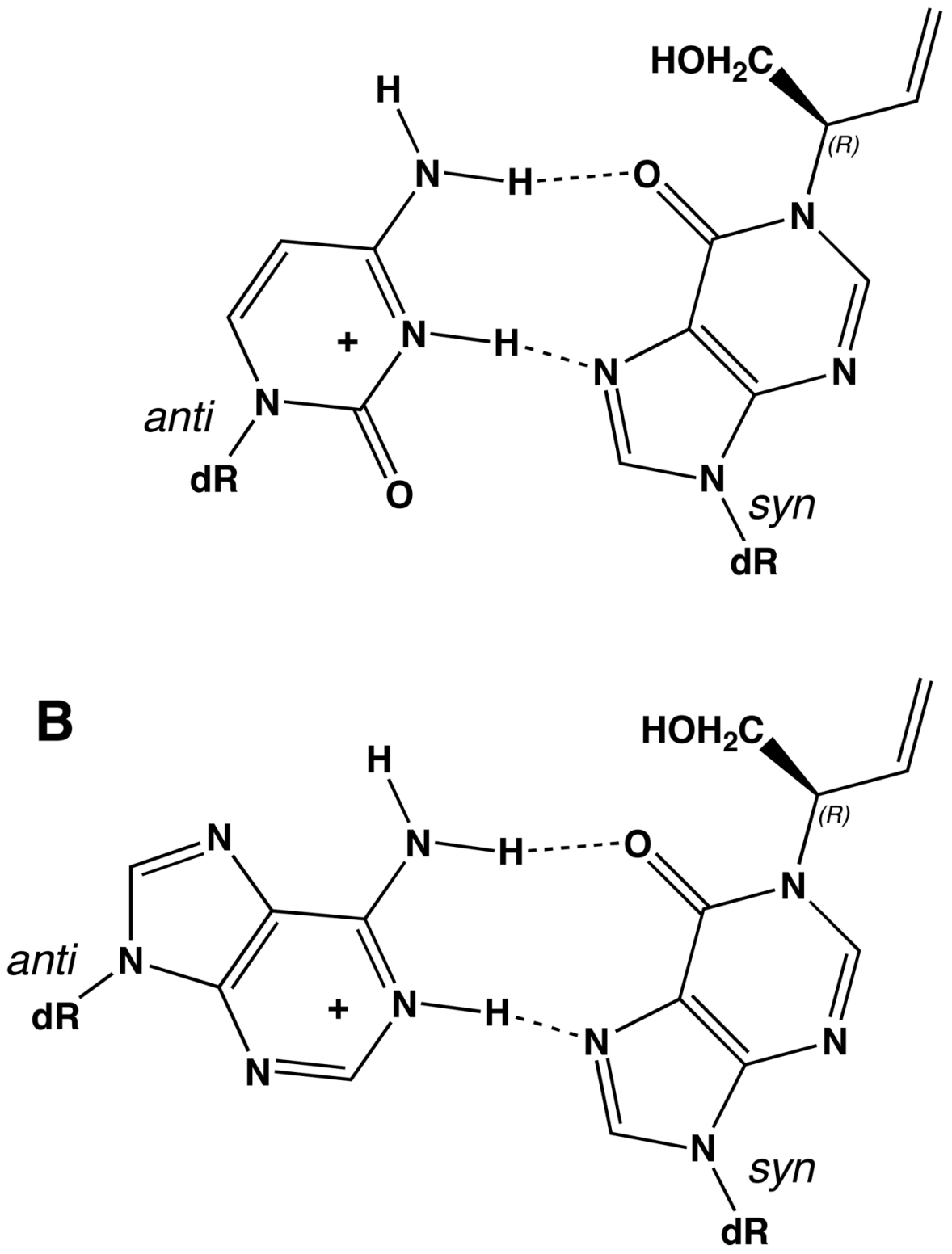

Scheme 3.

A. Formation of a Protonated Hoogsteen Pair Between the N1-(1-Hydroxy-3-buten-2(R)yl)-2'-deoxyinosine Adduct and Cytosine. B. Formation of a Protonated Hoogsteen-like Pair Between the N1-(1-Hydroxy-3-buten-2(R)-yl)-2'-deoxyinosine Adduct and Adenine. 
Table 1

Analysis of the rMD-Generated Structures of the ras61 R-N1-BDO-(61,2) adduct.

\begin{tabular}{|c|c|}
\hline \multicolumn{2}{|l|}{ NMR restraints } \\
\hline total no. of distance restraints & 394 \\
\hline interresidue distance restraints & 125 \\
\hline intraresidue distance restraints & 253 \\
\hline DNA-BDE distance restraints & 16 \\
\hline \multicolumn{2}{|l|}{ Total torsion angle restraints } \\
\hline sugar pucker restraints & 80 \\
\hline backbone torsion angle restraints & 71 \\
\hline \multicolumn{2}{|l|}{ empirical restraints } \\
\hline H-bonding restraints & 46 \\
\hline dihedral planarity restraints (in XPLOR) & 20 \\
\hline \multicolumn{2}{|l|}{ 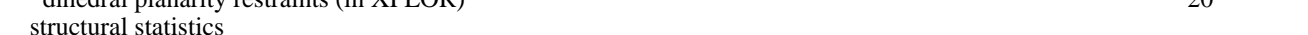 } \\
\hline NMR R-factor $\left(\mathrm{R}_{1}{ }^{x}\right)^{a, b, c}$ & $9.25 \times 10^{-2}$ \\
\hline rmsd of NOE violations $(\AA)$ & $2.32 \times 10^{-2}$ \\
\hline no. of DNA NOE violations $>0.15 \AA$ & 6 \\
\hline \multicolumn{2}{|l|}{ pairwise rmsd $(\AA)$ over all atoms } \\
\hline IniA vs. IniB & 5.92 \\
\hline IniA vs. rMDA & 7.34 \\
\hline IniB vs. rMDB & 2.17 \\
\hline rMDA vs rMDB & 0.99 \\
\hline rMDA vs rMDA & 1.35 \\
\hline rMDB vs rMDB & 0.96 \\
\hline$<\mathrm{rMDA}>$ vs. rMDA $\mathrm{avg}_{\mathrm{a}}$ & $0.89 \pm 0.28$ \\
\hline$\left\langle\right.$ rMDB $>$ vs. rMDB ${ }_{\text {avg }}^{\text {avg }}$ & $0.62 \pm 0.21$ \\
\hline
\end{tabular}

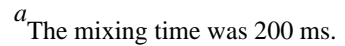

${ }^{b} \mathrm{R}_{1} x=\sum\left|\left(\mathrm{a}_{\mathrm{O}}\right) i^{1 / 6}-\left(\mathrm{a}_{\mathrm{c}}\right)_{i}^{1 / 6}\right| / \Sigma\left|\left(\mathrm{a}_{\mathrm{O}}\right)_{i}{ }^{1 / 6}\right|$, where $\mathrm{a}_{\mathrm{O}}$ and $\mathrm{a}_{\mathrm{c}}$ are the intensities of observed (non-zero) and calculated NOE cross-preaks.

${ }^{c}<$ rMDA>, represents a group of 8 converged structures starting from IniA; $\langle\mathrm{rMDB}\rangle$, represents a group of 8 converged structures starting from IniB. $\mathrm{rMDA}_{\text {avg }}$ represents the potential energy minimized average structure of all $8 \mathrm{rMD}$ calculations starting with A-form DNA rMDB avg represents the potential energy minimized average structure of all $8 \mathrm{rMD}$ calculations starting with B-form DNA. The comparisons: rMDA vs rMDB, rMDA vs rMDA, rMDB vs rMDB, represent the maximum observed pairwise rmsd over all atoms between these groups 